\title{
Vinasse application and cessation of burning in sugarcane management can have positive impact on soil carbon stocks
}

Caio F Zani ${ }^{\text {Corresp., }}$ 1, 2 , Arlete S Barneze $^{2,3}$, Andy D Robertson ${ }^{2,4}$, Aidan M Keith ${ }^{2}$, Carlos E P Cerri ${ }^{5}$, Niall P McNamara $^{2}$, Carlos C Cerri ${ }^{1,5}$

${ }^{1}$ Centro de Energia Nuclear na Agricultura, Universidade de São Paulo, Piracicaba, São Paulo, Brazil

2 Lancaster Environment Centre, Centre for Ecology \& Hydrology, Lancaster, United Kingdom

3 Soil and Ecosystem Ecology Laboratory, Lancaster Environment Centre, Lancaster University, Lancaster, United Kingdom

4 Institute of Biological and Environmental Sciences, University of Aberdeen, Aberdeen, United Kingdom

5 Departamento de Ciência do Solo, Escola Superior de Agricultura "Luiz de Queiroz", Universidade de São Paulo, Piracicaba, Brazil

Corresponding Author: Caio F Zani

Email address: caiozani@usp.br

Bioenergy crops, such as sugarcane, have the potential to mitigate greenhouse gas emissions through fossil fuel substitution. However, increased sugarcane propagation and recent management changes have raised concerns that these practices may deplete soil carbon (C) stocks, thereby limiting the net greenhouse gas benefit. In this study, we use both a measured and modelled approach to evaluate the impacts of two common sugarcane management practices on soil $\mathrm{C}$ sequestration potential in Brazil. We explore how transitions from conventional (mineral fertiliser/burning) to improved (vinasse application/unburned) practices influence soil C stocks in total and in physically fractionated soil down to 1 metre. Results suggest that vinasse application leads to an accumulation of soil $\mathrm{C}$ of $0.55 \mathrm{Mg} \mathrm{ha}^{-1} \mathrm{yr}^{-1}$ at $0-30 \mathrm{~cm}$ depth and applying unburned management led to gains of $\sim 0.7 \mathrm{Mg} \mathrm{ha}^{-1} \mathrm{yr}^{-1}$ at 30-60 cm depth. Soil C concentration in the Silt+Clay fraction of topsoil $(0-20 \mathrm{~cm})$ showed higher $\mathrm{C}$ content in unburned management but it did not differ under vinasse application. The CENTURY model was used to simulate the consequences of management changes beyond the temporal extent of the measurements. Simulations indicated that vinasse was not the key factor driving increases in soil $\mathrm{C}$ stocks but its application may be the most readily available practice to prevent the soil $\mathrm{C}$ losses under burned management. Furthermore, cessation of burning may increase topsoil C by $40 \%$ after $\sim 50$ years. These are the first data comparing different sugarcane management transitions within a single area. Our findings indicate that both vinasse application and the cessation of burning can play an important role in reducing the time required for sugarcane ethanol production to reach a net $C$ benefit (payback time). 
1 Vinasse application and cessation of burning in sugarcane management can have positive impact

2 on soil carbon stocks

3

4 CAIO F. ZANI ${ }^{\mathrm{a}, \mathrm{b}, *}$, ARLETE S. BARNEZE ${ }^{\mathrm{b}, \mathrm{c}}$, ANDY D. ROBERTSON $^{\mathrm{b}, \mathrm{d}}$, AIDAN M. KEITH $^{\mathrm{b}}$,

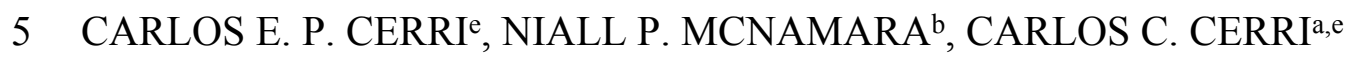

7 a Centro de Energia Nuclear na Agricultura, Universidade de São Paulo, Av. Centenário, 303, São

8 Dimas, Piracicaba, SP, 13400-970, Brazil

9 b Centre for Ecology \& Hydrology, Lancaster Environment Centre, Library Avenue, Bailrigg,

10 Lancaster, England, LA1 4AP, United Kingdom

$11^{c}$ Soil and Ecosystem Ecology Laboratory, Lancaster Environment Centre, Lancaster University,

12 Lancaster, England, LA1 4YQ, United Kingdom

13 d Institute of Biological and Environmental Sciences, University of Aberdeen, 23 St Machar Drive,

14 Aberdeen, Scotland AB24 3UU, United Kingdom

15 e Departamento de Ciência do Solo, Escola Superior de Agricultura "Luiz de Queiroz", Av. Pádua

16 Dias, 11, Piracicaba, SP, 13418-900, Brazil

18 *corresponding author: Caio Zani, School of Natural and Environmental Sciences, Newcastle

19 University, Kings Road, Newcastle upon Tyne, England, NE1 7RU, United Kingdom

20 E-mail address: caiozani@usp.br 


\section{Abstract}

23 Bioenergy crops, such as sugarcane, have the potential to mitigate greenhouse gas emissions

24 through fossil fuel substitution. However, increased sugarcane propagation and recent

25 management changes have raised concerns that these practices may deplete soil carbon (C) stocks,

26 thereby limiting the net greenhouse gas benefit. In this study, we use both a measured and modelled

27 approach to evaluate the impacts of two common sugarcane management practices on soil C 28 sequestration potential in Brazil. We explore how transitions from conventional (mineral

29 fertiliser/burning) to improved (vinasse application/unburned) practices influence soil C stocks in

30 total and in physically fractionated soil down to 1 metre. Results suggest that vinasse application

31 leads to an accumulation of soil $\mathrm{C}$ of $0.55 \mathrm{Mg} \mathrm{ha}^{-1} \mathrm{yr}^{-1}$ at $0-30 \mathrm{~cm}$ depth and applying unburned

32 management led to gains of $\sim 0.7 \mathrm{Mg} \mathrm{ha}^{-1} \mathrm{yr}^{-1}$ at $30-60 \mathrm{~cm}$ depth. Soil $\mathrm{C}$ concentration in the

33 Silt+Clay fraction of topsoil $(0-20 \mathrm{~cm})$ showed higher $\mathrm{C}$ content in unburned management but it

34 did not differ under vinasse application. The CENTURY model was used to simulate the 35 consequences of management changes beyond the temporal extent of the measurements.

36 Simulations indicated that vinasse was not the key factor driving increases in soil C stocks but its 37 application may be the most readily available practice to prevent the soil $\mathrm{C}$ losses under burned 38 management. Furthermore, cessation of burning may increase topsoil C by $40 \%$ after $\sim 50$ years.

39 These are the first data comparing different sugarcane management transitions within a single area.

40 Our findings indicate that both vinasse application and the cessation of burning can play an

41 important role in reducing the time required for sugarcane ethanol production to reach a net $\mathrm{C}$ 42 benefit (payback time). 
44

45

46

47

48

49

50

51

52

\section{Introduction}

Sugarcane has the potential to contribute significantly towards a renewable energy future (Goldemberg et al. 2014; OECD/FAO 2013). Ethanol production derived from sugarcane has become of global interest due to its potential to mitigate emissions of greenhouse gases (GHGs) through fossil fuel substitution (Goldemberg et al. 2014). There are, however, concerns that bioenergy-driven land use change (LUC) may adversely impact soil carbon (C) stocks (Guo \& Gifford 2002) and increase the amount of time required before a biofuel feedstock can achieve a net positive GHG benefit when displacing fossil fuels (i.e., its payback time) (Fargione et al. 2008; Mello et al. 2014).

Whilst LUC to sugarcane always impacts the overall $\mathrm{C}$ balance, the extent of this impact is often management-specific and therefore exact payback time for any given site is directly related to how it is managed (Davis et al. 2013; Walter et al. 2011). Management practices which increase bioenergy crop yields, increase soil C accumulation and decrease GHG emissions are an important part of sustainable land use in light of climate change (Lal 2004; Smith et al. 2012). With the expected increase in sugarcane use as a biofuel in the near future (Goldemberg et al. 2014) the current and expanding sugarcane areas have received considerable attention regarding two key management practices: 1) the fate of by-products from the ethanol cycle to the field (e.g., vinasse) and 2) reduced biomass removal due to a transition from traditional pre-harvest burning to an unburned management.

Vinasse is produced from the processes of producing ethanol from sugarcane; for each litre (L) of sugarcane ethanol produced around $13 \mathrm{~L}$ of this liquid by-product is generated. Sugarcane vinasse is a source of soluble $\mathrm{C}$ but also has a high organic content (chemical oxygen demandCOD, $\left.50-150 \mathrm{~kg} \mathrm{~m}^{-3}\right)$ and is highly concentrated in potassium $(\mathrm{K})\left(\sim 2 \mathrm{~kg} \mathrm{~m}^{-3}\right)$ (Christofoletti et al. 
67 2013). A moderate amount of other minerals, such as nitrogen $(\mathrm{N})$, calcium $(\mathrm{Ca})$, phosphorus $(\mathrm{P})$

68 and magnesium $(\mathrm{Mg})\left(0.28,0.33,0.10\right.$ and $0.13 \mathrm{~kg} \mathrm{~m}^{-3}$, respectively) are also found in vinasse (de

69 Resende et al. 2006). Vinasse can be applied by irrigation (ferti-irrigation) to sugarcane fields as a

70 simple and inexpensive soil fertiliser which reduces chemical input requirements (Laime et al.

71 2011) and increases sugarcane yields (de Resende et al. 2006). It is estimated that over $80 \%$ of São

72 Paulo State is under vinasse ferti-irrigation (Fronzalia 2007). A recent evaluation by Prado et al.

73 (2013) also suggests that vinasse application to sugarcane fields can deliver benefits to the soil

74 when applied at appropriate levels $\left(\sim 200 \mathrm{~m}^{3} \mathrm{ha}^{-1}\right)$ including an increase in soil $\mathrm{C}$ stocks (de

75 Resende et al. 2006). By contrast, an inappropriate and/or overuse of vinasse application might

76 cause environmental issues including soil salinisation (Christofoletti et al. 2013) and potential

77 nutrient discharge into water bodies leading to eutrophication (Có Júnior et al. 2008). Furthermore,

78 recent studies suggest that vinasse leads to GHG emissions during its storage, transportation and

79 application to the soil (Oliveira et al. 2013; Oliveira et al. 2015). Whilst the vast majority of studies

80 have focused on GHG emissions and perceive vinasse discharge as a pollutant (see review by

81 Fuess et al. 2014) there is also a need to consider its potential benefits to soil C. To the best of our

82 knowledge, there is only one study evaluating the impacts of vinasse application on soil C stocks,

83 reporting a non-significant increase of $0.25 \mathrm{Mg} \mathrm{ha}^{-1} \mathrm{yr}^{-1}$ in the top $20 \mathrm{~cm}$ (de Resende et al. 2006).

84 The burning sugarcane residues on the soil surface prior to manual harvesting has historically

85 been a common management practice in Brazil and worldwide. This burning process facilitates

86 manual harvesting and subsequent sugarcane transport by removing leaf material but the cane

87 remains intact. This management practice is now considered to be particularly detrimental both in

88 terms of climate change and human health due to GHG and black C emissions (Cançado et al.

89 2006; Galdos et al. 2013). Recent studies highlight that unburned sugarcane management can 
90 enhance $\mathrm{C}$ sequestration in soils, with a reported increase in topsoil $(30 \mathrm{~cm}) \mathrm{C}$ stocks of $1.50 \mathrm{Mg}$

$91 \mathrm{ha}^{-1} \mathrm{yr}^{-1}$ (Cerri et al. 2011; Galdos et al. 2010). However, these previous studies did not use a paired

92 site approach to directly examine the impacts of cessation of burning (i.e., the transition in

93 management practices). Furthermore, most previous sugarcane studies only examine change in

94 topsoil; comparable research under European perennial bioenergy crops has demonstrated that C

95 in deeper soil layers must be included in any bioenergy sustainability assessment (Keith et al. 2015;

96 Rowe et al. 2016; Walter et al. 2015). While there are undeniable benefits regarding cessation of

97 burning such management changes can also lead to soil compaction from mechanised harvesting,

98 decreased crop yields, and requiring more frequent soil tillage (Silva-Olaya et al. 2013; Walter et

99 al. 2014).

100 Management mediated changes in soil $\mathrm{C}$ stocks might be underpinned by changes in the soil 101 organic matter (SOM) C associated with different soil particle sizes and mineralogical

102 compositions (Christensen 1992). Evaluating the C content of different particle-size fractions can

103 therefore improve our understanding of the mechanisms by which the soil $\mathrm{C}$ stabilisation occurs,

104 as well as the sensitivity of SOM content in response to management practice (Brandani et al.

105 2016). Recent studies appraising different sugarcane management practices have reported changes

106 in C measured in different soil fractions (Brandani et al. 2016; Lisboa et al. 2009; Signor et al.

107 2014). Brandani et al. (2016) highlighted that the cessation of burning combined with organic

108 fertiliser inputs is able to accumulate soil $\mathrm{C}$ in at least three SOM fractions $(<53 \mu \mathrm{m} ; 75-53 \mu \mathrm{m}$

109 and 2000-75 $\mu \mathrm{m}$ ). Additionally, Signor et al. (2014) showed that cessation of burning can also lead

110 to increased soil C stocks particularly in organo-mineral complexes that typically have a higher

111 mean residence time in the soil than particulate organic matter. Ultimately, research into the

112 impacts of changing management practices on soil $\mathrm{C}$ stocks and soil $\mathrm{C}$ fractions can help reduce 
113 the uncertainty of calculating payback time associated with sugarcane grown for ethanol

114 production (such as those reported by Mello et al. (2014)).

115 Empirical research of soil C dynamics often provide us with a single snapshot in time (e.g.,

116 a paired-site approach). To accurately determine the true long-term impacts of a management

117 change, we must also compliment these measurements with informed predictions that can

118 interpolate between the individual, measured time-points. Mathematical models can help with this

119 by simulating the potential influence that different management practices have on soil C stocks.

120 One of the most well-known ecosystem models (the CENTURY model version 4.0; Parton et al.

121 (1987) simulates elemental cycling through plant production and soils, and has been validated to

122 accurately simulate annual and perennial crops, forests and pastures (Cerri et al. 2007; Cong et al.

123 2014; Parton \& Rasmussen 1994). CENTURY has also been reported to provide reliable

124 simulations of sugarcane plantations (Brandani et al. 2015; Galdos et al. 2009b; Galdos et al.

125 2009c; Vallis et al. 1996) and thus can improve our understanding in the context of management 126 practice changes.

127 This study aims to address the impacts of vinasse application and the cessation of burning 128 on soil $\mathrm{C}$ stocks at the same location. Using a paired-site approach with previous management 129 practices as a reference, we explore how transitions to new management might influence soil C 130 stocks and $\mathrm{C}$ fractions, down to 1 metre. Additionally, we use the process-based model, 131 CENTURY, to evaluate if either vinasse application, burning, cessation of burning or a 132 combination of these practices, could result in longer term changes in soil C stocks. A simplistic 133 recalculation of the payback time for soil $\mathrm{C}$ stocks and sugarcane ethanol is also provided taking 134 into consideration the management changes assessed here. 


\section{2. Material and methods}

2.1 Site selection and description

A paired-site (space-for-time) approach was used at two locations to quantify changes in soil

138 C stocks after changes in management practices, with the previous and the current management at

139 the same location. The pairings were deemed suitable since they had similar soil type, climatic

140 conditions and a reference sugarcane management area to pair with the new management

141 approach, a no vinasse-to-vinasse (NV-to-V) and a burned-to-unburned (B-to-UB) comparison.

142 These sites were located in Ourinhos, São Paulo State (22 59’ S, 49 52’ W, $492 \mathrm{~m}$ above sea level)

143 (Fig. S1). The climate of the region is classified as tropical savanna with hot humid summers and

144 cold dry winters according to the Köppen classification (Cwa tropical). The average annual

145 precipitation and temperature are $1321 \mathrm{~mm}$ and $22.8^{\circ} \mathrm{C}$, respectively (Fig. S2).

146 The soil was classified as Rhodic Ferralsol (FAO 2014); soil properties are shown in Tables

147 S1 and S2. Soil under typical native vegetation (F site) in the region, used as a baseline for 148 modelling approaches, was sampled nearby of the study sites (Lat.: $23^{\circ} 05^{\prime} 08^{\prime}$ ' S; Long.:

$149 \quad 49^{\circ} 37^{\prime} 52^{\prime}$ ' W), having the same soil type as the sugarcane planted areas (more information can be

150 found in Cherubin et al. (2015); Franco et al. (2015)). This native vegetation was identified as a

151 seasonal semi-deciduous forest within the Atlantic forest biome, compromising a transitional

152 region between the Atlantic rainforest and Cerrado vegetation (Cherubin et al. 2015; Franco et al. 153 2015).

155 2.2 Management comparisons

$156 \quad 2.2 .1$ No Vinasse (NV) to Vinasse (V) 

conversion from pasture. Since 2004, 12.72 ha of this area has received vinasse application (V

159 site), whereas the remaining area has continued to receive conventional mineral fertiliser (NV site)

160 (Fig. 1A). In 2008 and 2009 mechanised harvesting was also introduced at the V and NV sites

161 respectively, and before that burning practice followed by manual harvesting was employed at

162 both. Management included, in addition to vinasse conventional fertiliser, $\mathrm{N}$ application in 2013

163 (164 $\mathrm{kg} \mathrm{ha}^{-1}$ and $192 \mathrm{~kg} \mathrm{ha}^{-1}$ for $\mathrm{V}$ and NV, respectively), and P application in January 2012 (120

$164 \mathrm{~kg} \mathrm{ha}^{-1}$, at both the V and NV sites) and tillage in 2011. At the NV site, potassium chloride (KCl)

165 was applied as an inorganic fertiliser $\left(520 \mathrm{~kg} \mathrm{ha}^{-1}\right)$ at the time of sugarcane planting, whilst vinasse

166 was applied in the $\mathrm{V}$ site each year since 2004 at an average rate of $268 \mathrm{~m}^{3} \mathrm{ha}^{-1}$. Taking into account

167 the $\mathrm{K}$ content typically found in the vinasse (from 0.84 to $1.8 \mathrm{~g} \mathrm{~L}^{-1}$ ) these applications correspond 168 to a total rate of around $440 \mathrm{~kg} \mathrm{ha}^{-1}$ of $\mathrm{K}$ concentration (Oliveira et al. 2013; Oliveira et al. 2015).

2.2.2 Burned (B) to Unburned (UB)

172 (Fig. 1B). The area was converted to sugarcane in 1993 but prior to sugarcane, where the UB site

173 is located, annual cropping was used for 10 years. From 1993 to 2001, the whole area was

174 harvested using burning methods. From 2001 the plantation was split into two: burned practices 175 with manual harvesting continued at one site (B site, $15.48 \mathrm{ha}$ ), and ceased at another, employing 176 mechanised harvesting instead (UB site, 15.02 ha) (Fig. 1B). This particular change in the 177 management also resulted in a straw deposition in the soil surface of roughly 10 to $20 \mathrm{Mg} \mathrm{ha}^{-1}$ 178 every year. In the year of sampling (2013), the B site had been under the burned management for 
17920 years, while the UB site had undergone 8 years of burned management practice followed by 12 180 years of unburned practices.

181 The B and UB sites were cultivated by conventional tillage with added mineral fertilisers.

182 Nitrogen fertiliser was consistently applied at a rate of $86 \mathrm{~kg} \mathrm{ha}^{-1} \mathrm{yr}^{-1}$ from 2009. During planting,

183 the B site received $119 \mathrm{~kg} \mathrm{ha}^{-1}$ of phosphorus $(\mathrm{P})$ and $521 \mathrm{~kg} \mathrm{ha}^{-1}$ of potassium $(\mathrm{K})$, whereas the

184 UB site received $494 \mathrm{~kg} \mathrm{ha}^{-1}$ of $\mathrm{K}$ with no $\mathrm{P}$ addition. The last tillage of the sites occurred in 2008 185 and 2011 for $\mathrm{U}$ and $\mathrm{UB}$, respectively.

2.3 Approach, sampling method and measurements

The experimental design followed the schematic suggested by Cerri et al. (2013) and used by Mello et al. (2014) (Fig. S3), but included more detailed sampling of soil layers. Specifically, the sampling grid for each study field comprised nine trenches distributed in $3 \times 3$ grid spaced at $50 \mathrm{~m}$ apart dug in each management site and covering approximately 1 ha $(100 \times 100 \mathrm{~m})$. In each of the three deeper trenches (Fig. S3; dimensions $120 \times 120 \times 120 \mathrm{~cm}$ ) soil samples were taken in $10 \mathrm{~cm}$ increments to $100 \mathrm{~cm}$, from the opposing walls of the trench to obtain representative soil samples between and within plant rows. Shallow trenches (Fig. S3; six trenches with dimensions $40 \times 40 \times 40 \mathrm{~cm}$ ) were sampled to $30 \mathrm{~cm}$ depth also in $10 \mathrm{~cm}$ increments, only from one wall. In each layer of each trench two types of samples were taken, one for bulk density (BD), C and N assessments, using stainless steel rings with a diameter and height of $5 \mathrm{~cm}\left(98.17 \mathrm{~cm}^{3}\right.$ internal ring volume) (78 samples), and another for chemical and physical analyses (60 samples). All soil samples were taken in July 2013. 
Soil samples taken from the $120 \mathrm{~cm}$ deep trenches were used to characterise the study sites

203 in terms of texture (sand, silt and clay content), soil $\mathrm{pH}\left(\mathrm{CaCl}_{2}\right)$ and the concentration of macro

204 and micronutrients, according to the methods provided in Anderson \& Ingram (1989) and

205 EMBRAPA (1997) (Tables S1, S2). Soil texture was derived for each $10 \mathrm{~cm}$ increment down to

$206100 \mathrm{~cm}$, while only certain depths $(0-10 ; 10-20 ; 20-30 ; 40-50$ and $90-100 \mathrm{~cm})$ were used for the

207 other analyses (one composite sample from the three deeper trenches).

208 Soil moisture content was derived for all samples by drying the samples to constant weight

209 at $105^{\circ} \mathrm{C}$. To determine total $\mathrm{C}$ and $\mathrm{N}$, samples were ground to a fine powder and sieved to 150

$210 \mu \mathrm{m}$ prior to analyses. Total soil $\mathrm{C}$ and $\mathrm{N}$ were determined by dry combustion (Nelson \& Sommers

211 1996) using a Leco Truemac CN elementary analyzer (furnace at $1350^{\circ} \mathrm{C}$ in pure oxygen).

212

213 2.3.2 Physical fractionation

214 Physical fractionation was done according to Christensen (1992), which separates the

215 particle sizes soil by dispersion, wet sieving, flotation and sedimentation, followed by a subsequent

216 mass balance check. The method includes separation of the uncomplexed organic matter and

217 primary organo-mineral complexes (Christensen 2001).

218 The physical fractionation was carried out for all studied areas for the following depths: 0-

$21910 \mathrm{~cm}$, and 10-20 $\mathrm{cm}$ (3 replicates), 40-50 and 90-100 $\mathrm{cm}$ (1 replicate). Briefly, $20 \mathrm{~g}$ of dry soil

220 was sonicated in $70 \mathrm{~mL}$ of deionised water at $500 \mathrm{~W}$ for 15 minutes (providing roughly $13 \mathrm{~J}$ per

221 sample) using an ultrasonic processor (Model VC-505; Sonics Vibra Cell). Subsequently, the 222 sample was wet sieved through a $53 \mu \mathrm{m}$ sieve to separate the sand (assigned here as heavy fraction

$223 \mathrm{HF}>53 \mu \mathrm{m})$ and light-coarse particulate organic matter $(\mathrm{POM}>53 \mu \mathrm{m})$ from silt and clay $(\mathrm{S}+\mathrm{C}$

$224<53 \mu \mathrm{m}$ ) particles (Fig. S4). POM and HF fractions which were retained on the sieve were 
225 separated by flotation and sedimentation using deionised water $\left(1 \mathrm{~g} \mathrm{~cm}^{-3}\right)$ (Fig. S4). All resulting

226 fractions were air-dried, weighed and the sum of the fraction checked against the original $20 \mathrm{~g}$.

227 Lastly, the $\mathrm{C}$ content of each fraction was determined using dry combustion methods as for total

$228 \mathrm{C}$ and $\mathrm{N}$ analyses.

229

230 2.3.3 Soil C stock and Payback time recalculation

231 Soil $\mathrm{C}$ stock was calculated for each $10 \mathrm{~cm}$ layer by relating the soil $\mathrm{C}$ concentration to bulk

232 density and depth increment. As soil C stock is directly related to bulk density which can be altered

233 by different management practices, it was necessary to adjust the mass of the soil layers being

234 compared to a reference mass (average bulk density from previous management carried out)

235 according to Ellert \& Bettany (1995). The use of C content and bulk density data were used to

236 make the comparison of soil C stocks between the paired sites in order to derive the equivalent soil

237 mass across each management comparison.

238 The payback time for the soil $\mathrm{C}$ stock debt and sugarcane ethanol production was

239 recalculated following the same method utilised by Mello et al. (2014) but here considering the

240 management change (no vinasse-to-vinasse and burned-to-unburned) effects. The response ratios

241 denoted as management change factors (i.e., the proportional change in the soil $\mathrm{C}$ stocks due to

242 management change) were calculated using the average soil $\mathrm{C}$ stocks for each management

243 practice assessed over the layer increments $0-30,0-50$ and $0-100 \mathrm{~cm}$. The management change

244 factor higher than 1 indicates soil C stock gain while values lower than 1 represents losses. The C

245 debt $\left(\mathrm{Mg} \mathrm{CO}_{2} \mathrm{ha}^{-1}\right)$ after 20 years due to either LUC from pasture or cerrado vegetation to

246 sugarcane plantations reported by Mello et al. (2014) were used to recalculated the payback time. 
247 The estimated payback time included our findings after management changes (NV-to-V and B-to-

$248 \mathrm{UB}$ ), plus the sugarcane ethanol offset of $9.8 \mathrm{Mg} \mathrm{CO}_{2} \mathrm{ha}^{-1} \mathrm{yr}^{-1}$ reported by Fargione et al. (2008).

249

$250 \quad 2.4$ CENTURY model description and assessment

251 The CENTURY model version 4.0 was used to simulate long-term changes in both soil C 252 stocks for the upper $20 \mathrm{~cm}$ of the soil profile and to simulate sugarcane yields. Briefly, CENTURY

253 is a mechanistic model at ecosystem scale that operates on a monthly time step; it has interacting 254 crop production routines and soil modules to partition SOM into three pools with different turnover 255 times controlled by specific decomposition rates (1. active, fast turnover, 2. intermediate, medium 256 turnover, 3. passive, slow turnover).

2.4.1 Initialisation, parameterisation and assessment of the model

The model was initialised by inputting site-specific features including soil texture data, bulk 260 density and $\mathrm{pH}$ from native forest vegetation ( $\mathrm{F}$ site) nearby the sugarcane study sites (Cherubin et al. 2015; Franco et al. 2015). Meteorological inputs including mean precipitation and monthly temperatures (minimum and maximum), taken by the Instituto Nacional de Metereologia (INMET 2016) from the weather station located in Presidente Prudente (170 km from the sites), were used for the period between 1961-2008. Site specific meteorological inputs were used from 2009 to 2013, taken from a weather station located at the São Luiz mill (Ourinhos). The combination of these two stations was necessary due to limited weather data being available for the specific study 267 site prior to 2009.

Pre-cultivation conditions were first run to an equilibrium state (7000 years) under native vegetation. Model parameterisation was required for this native vegetation situation, since the 
270 location of native vegetation is under a transitional situation between Cerrado vegetation and

271 Atlantic Rainforest. The parameterisation was made in accordance with data reported in Cherubin

272 et al. (2015); Franco et al. (2015) and used the average between default values of Cerrado and

273 Atlantic rainforest specified by CENTURY for the remaining parameters. A fire event was

274 scheduled every 120 years during the equilibrium spin-up to simulate forest disturbance based on

275 the premise that there is a gap formation due to the occurrence of tree mortality and tree-fall (Cerri

276 et al. 2004). Subsequent checks were performed to ensure that simulated above (leaves, branches

277 and tree large woods) and belowground (roots) biomass was in line with measured data from

278 published studies (Cunha et al. 2009; Vieira et al. 2011). Once the SOM reached the equilibrium

279 state, a deforestation event was simulated in accordance with the LUC procedure parameterised

280 by Cerri et al. (2004), which involves slash and burn of the native vegetation.

281 Each simulation scenario was scheduled to represent the management history of each 'site',

282 summarised in Fig. 1. Soil texture was kept constant across each study sites (66, 19 and $14 \%$ for

283 clay, sand and silt, respectively) as the soil under native vegetation and our sampled sugarcane

284 sites were similar. Owing the lack of information about pasture and soybean management used

285 prior to conversion into sugarcane plantations, we assumed a typical management practice (i.e.,

286 degraded pasture), characterised by low to moderate productivity mainly caused by the lack of soil

287 management (liming, fertilisation) and overgrazing, as well as monocropping and conventional

288 soil tillage for soybean (plowing and disking) as reported by Batlle-Bayer et al. (2010) and Maia

289 et al. (2010). Simulated results of these practices were validated (above and belowground) in

290 relation to biomass productivity stated in other studies (Bordin et al. 2008; Finoto et al. 2012;

291 Lilienfein \& Wilcke 2003). The model was run with sugarcane cultivation based on 
292 parameterisation developed and reported by Galdos et al. (2009b); Galdos et al. (2009c) (Table 293 S3, S4, S5).

294

295 2.4.2 Long-term Scenarios

296 Simulations were extended beyond the 2013 measurement date to predict the effects of 297 management practice changes up to 2100 , where a near-equilibrium state of soil C stocks was 298 achieved for all management practices. In this procedure, monthly weather conditions were 299 established on the average historic data (1961-2013) assuming no climate change or variation in 300 atmospheric $\mathrm{CO}_{2}$ concentrations. The sugarcane crop cycle was fixed to imply a rotation with 6 301 years of annual harvest followed by conventional tillage and immediate replanting after the $6^{\text {th }}$

302 harvest. Additional simulations were performed to evaluate the influence of varying application 303 rates of vinasse, including a combination of a burned management and vinasse application at high 304 and low application rates, 400 and $100 \mathrm{~m}^{3} \mathrm{ha}^{-1} \mathrm{yr}^{-1}$ respectively.

305

306

2.5 Statistical analyses

Differences in soil C stock depth profiles due to management practice changes were tested 308 with a bootstrap re-sampling and Loess regression approach (Keith et al. 2016). Firstly, the combined land management data (i.e., NV-to-V and B-to-UB) was re-sampled by bootstrap with replacement $(\mathrm{n}=1000)$. These data were then modelled using Loess regression and the bootstrap

311 samples used to generate $95 \%$ confidence intervals around a modelled soil C profile. This

312 represented the null hypothesis that there was no difference between the land management

313 practices. The data from the new land management practice only was then modelled using Loess

314 regression; if the modelled line for this soil $\mathrm{C}$ profile sat outside the confidence interval based on 
315 the null hypothesis, it was inferred that soil C stocks were significantly different. Generalised

316 linear model (GLM) was fitted to test differences in soil C content in soil fractions (POM $>53$

$317 \mu \mathrm{m} ; \mathrm{HF}>53 \mu \mathrm{m}$ and $\mathrm{S}+\mathrm{C}<53 \mu \mathrm{m})$ in response to management changes ( $\mathrm{NV}$-to- $\mathrm{V}$ and $\mathrm{B}$-to-UB)

318 for $0-10 ; 10-20$ and top $0-20 \mathrm{~cm}$ depth. All statistical analysis was carried out in the $\mathrm{R}$

319 programming language 3.4.3 (R Development Core Team 2018).

320 For the CENTURY modelling approaches the correlation coefficient (r) and root mean

321 square error (RMSE) were used to compare simulated and measured soil C stocks, in accordance

322 with Smith et al. (1997).

323

324 


\section{3. Results}

326

327 3.1 Soil C stock

328 3.1.1 No Vinasse (NV) to Vinasse (V)

329 The differences in soil $\mathrm{C}$ stocks between vinasse management practices were significant at

330 shallow depths in the soil profile (Fig, 2). The V management site had significantly more soil C

331 stocks at all points in the profile from 0 to $30 \mathrm{~cm}$ depth whereas the NV had slightly more soil $\mathrm{C}$

332 from 60 to $80 \mathrm{~cm}$ below the soil surface (Fig. 2). The other layers $(40-50,80-90$ and $90-100 \mathrm{~cm})$

333 did not differ between NV and V site. Within the top $100 \mathrm{~cm}$, the highest soil C stocks were found

334 in the top $10 \mathrm{~cm}$, with 31.0 and $22.6 \mathrm{Mg} \mathrm{C} \mathrm{ha}^{-1}$ under $\mathrm{V}$ and $\mathrm{NV}$, respectively.

335 These differences in specific depths also resulted in a response ratio higher than 1 for the 336 three-layer increments $0-30,0-50$ and $0-100 \mathrm{~cm}(1.10 ; 1.14$ and 1.09 for, respectively) indicating 337 soil $\mathrm{C}$ stock gain after a change in the management practice (Table 1). Based on vinasse being first 338 applied early in 2004, the management practice change from NV to V led to an accumulation of 339 soil $\mathrm{C}$ of $0.55,1.11$ and 1.09 $\mathrm{Mg} \mathrm{C} \mathrm{ha}^{-1} \mathrm{yr}^{-1}$, for 0-30, 0-50 and 0-100 cm, respectively. These

340 increments represent $\mathrm{C}$ sequestration of 2.0, 4.1 and 4.0 $\mathrm{Mg} \mathrm{CO}_{2}$-eq ha- $\mathrm{yr}^{-1}$ between 2004 and

3412013 and a decrease in the payback time for soil C stocks in ethanol production under vinasse-

342 based management for the 0-30, 0-50 and 0-100 cm layer intervals (Table 2).

343

344 3.1.2 Burned (B) to Unburned (UB)

345 Soil C stocks increased significantly following cessation of burning managements from 30-

$34660 \mathrm{~cm}$ in the soil profile, but did not differ for the top $20 \mathrm{~cm}$ of the profile or between 60 and 100

$347 \mathrm{~cm}$ (Fig. 3). Under B management, soil C stocks were largest in the surface from 0-10 $\mathrm{cm}(28.2$ 


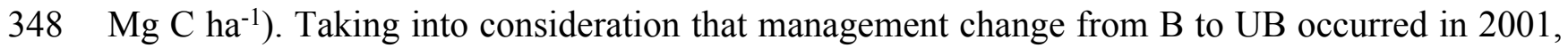

34912 years before soil sampling, it led to an increase of $\sim 0.7 \mathrm{Mg} \mathrm{C} \mathrm{ha}^{-1} \mathrm{yr}^{-1}$ for the depth interval

350 from 30 to $60 \mathrm{~cm}$ depth.

351 This soil $\mathrm{C}$ stock increase at specific depths led to management change response ratios

352 greater than 1 for all of the layer intervals assessed after management change $(1.03 ; 1.12$ and 1.04

353 for 0-30, 0-50 and 0-100 cm, respectively) (Table 1). This result also suggests $\mathrm{C}$ accumulation of

$3540.17,0.83$ and $0.40 \mathrm{MgC} \mathrm{ha}^{-1} \mathrm{yr}^{-1}$ and a sequestration rate of $0.7,2.8$ and $1.4 \mathrm{Mg} \mathrm{CO}$-eq ha-1 $\mathrm{yr}^{-1}$

355 between 2002 and 2013 for the 0-30, 0-50 and 0-100 cm layer intervals, respectively. Consequently

356 this also resulted in a decrease in the time required for the sugarcane plantation to achieve a net $\mathrm{C}$

357 benefit under unburned management (Table 2).

358

359

3.2 Carbon in soil fractions

360 3.2.1 No vinasse (NV) to Vinasse management (V)

361 The average mass balance recovery of physical fractionation ranged between $97 \%$ and $98 \%$

362 (Table S6). Higher soil $\mathrm{C}$ concentration was found in the $\mathrm{S}+\mathrm{C}$ than either of the other $>53 \mu \mathrm{m}$

363 fractions for both NV and V management for the 0-10 and 10-20 cm layers and consequently for

364 the top 0-20 cm depth (Fig. 4). An enhanced C concentration was observed for 0-10 and 10-20 cm

365 depth under $\mathrm{V}$ management, which results in an increase of roughly $20 \%$ in $\mathrm{S}+\mathrm{C}$ fraction for the

366 top $20 \mathrm{~cm}$ depth, however, it did not significantly differ from NV management by the GLM (p >

367 0.05). The same was observed in the POM fraction, where the $\mathrm{V}$ management resulted in higher

368 soil $\mathrm{C}$ concentration at $10-20 \mathrm{~cm}$ depth but not statistically verified $(\mathrm{p}>0.05)$. For fraction and

369 depths where NV had higher soil C concentration, POM 0-10 and HF 10-20 cm depth, again the

370 results were not statistically significant at either case by the GLM (p > 0.05) (Fig. 4). 
372 3.2.2 Burned (B) to Unburned (UB)

373 Similar to the observations of vinasse-based management, a higher soil C concentration was

374 found in the $\mathrm{S}+\mathrm{C}$ at $0-10$ and $10-20 \mathrm{~cm}$ depth than either of the $>53 \mu \mathrm{m}$ fractions for both $\mathrm{B}$ and

375 UB management practices (Fig. 5). Considering the top $20 \mathrm{~cm}$ depth, UB management led to a 376 significant increase $\mathrm{C}$ concentration in $\mathrm{S}+\mathrm{C}$ fraction $(\mathrm{p}<0.05)$ (Fig. 5c). Interestingly, the opposite 377 was observed for both POM and HF fractions. The use of B management lead to higher soil C 378 concentration in the $0-10$ and $10-20 \mathrm{~cm}$ depth as well as to the top $20 \mathrm{~cm}$ depth, though these 379 differences were not statistically significant different $(\mathrm{p}>0.05)$.

380

381 3.3 Modelling soil C

382 Model simulations showed a good fit between simulated and measured values of soil C 383 stocks (0-20 cm depth) between all sugarcane sites assessed $\left(\mathrm{r}^{2}\right.$ value $=0.90, \mathrm{n}=4$ and $\mathrm{RMSE}=$ 384 1.72) (Fig. 6). Despite the model simulation underestimating empirical yield measurements (Fig. 385 S5), all study sites are within the measured variability and clearly demonstrate that the simulations 386 follow the measured trend for either management comparison.

387 Measured and modelled soil C stocks of the native forest for top $20 \mathrm{~cm}$ depth (53.6 and 52.5

$388 \mathrm{Mg} \mathrm{ha}^{-1}$ respectively, Fig. 6) showed that at the time of measurement (2013), this land use had a 389 higher soil C stock than all sugarcane sites, regardless of the management practice used. 390 Simulating LUC from native vegetation to pasture (34 years under pasture) predicted an average 391 soil $\mathrm{C}$ loss of $-0.25 \mathrm{Mg} \mathrm{ha}^{-1} \mathrm{yr}^{-1}$ (Fig. 7a). The highest soil $\mathrm{C}$ losses were observed where an annual 392 crop, mainly soybean, replaced pasture. This LUC followed by 10 years under soybean resulted 393 an average of soil $\mathrm{C}$ loss of $-1.5 \mathrm{Mg} \mathrm{ha}^{-1} \mathrm{yr}^{-1}$ (Fig. 7b). Soil $\mathrm{C}$ losses were also observed when the 
394 burned sugarcane plantations replaced pasture (-0.25 $\mathrm{Mg} \mathrm{ha}^{-1} \mathrm{yr}^{-1}$, Fig. 7a, b) while the opposite

395 trend was observed when sugarcane replaced annual crops, with soil $\mathrm{C}$ gains of $0.35 \mathrm{Mg} \mathrm{ha}^{-1} \mathrm{yr}^{-1}$ 396 (Fig. 7b).

397 The measured soil C stock differences between management practices in topsoil $(0-20 \mathrm{~cm})$ 398 were also observed in model simulations. In 2013 (year of soil sampling) simulation results showed 399 that vinasse application had higher soil $\mathrm{C}$ stocks than the site without vinasse (42.3 and $41.2 \mathrm{Mg}$ $400 \mathrm{ha}^{-1}$ respectively), and little difference between B and UB managements for 0-20 cm depth (44.8 401 and 44.1 $\mathrm{Mg} \mathrm{ha}^{-1}$, respectively) (Fig. 6). Since simulated soil C stocks were similar to measured 402 values, it helps to justify the use of an 87-year projection from 2013 to 2100.

403 Our simulated results indicate that sugarcane with vinasse application leads to an increase of 404 soil $\mathrm{C}$ of $0.64 \mathrm{Mg} \mathrm{ha}^{-1} \mathrm{yr}^{-1}$ from 2013 up to 2035 before a new equilibrium soil $\mathrm{C}$ stock is reached; 405 when no vinasse was applied, $\mathrm{C}$ stocks increased by $0.52 \mathrm{Mg} \mathrm{ha}^{-1} \mathrm{yr}^{-1}$ in the same interval period 406 (Fig. 7a). Subsequently, the model predicted minimal differences between the V and NV 407 managements between 2035 and 2100 (3.0 - 3.5 $\mathrm{Mg} \mathrm{C} \mathrm{ha}^{-1}$ for the top $20 \mathrm{~cm}$ ) (Fig. 7a). Long-term 408 projections also showed increased sugarcane yields under vinasse application (Fig. S5).

409 From 2050 onwards, the topsoil C stocks were relatively stable in both B and UB 410 management practices, but the burned site reported $23 \mathrm{Mg} \mathrm{C} \mathrm{ha}^{-1}$ less than the unburned site by 411 2100. The $\mathrm{C}$ stock in the unburned site increased by approximately $0.4 \mathrm{Mg} \mathrm{ha}^{-1} \mathrm{yr}^{-1}$ up to the 412 equilibrium state, from 2013 to 2050 (37 years), while the burned site reached a near-equilibrium 413 state rapidly following a decrease of soil C stock by $0.12 \mathrm{Mg} \mathrm{ha}^{-1} \mathrm{yr}^{-1}$ for the same period. Although 414 burned management have had higher measured yields until 2015, a long-term simulation (2015415 2100) indicates that unburned management will increase yield potential in relation to burned site 416 (Fig. S5). 
417 Model simulations also indicated that the interaction of vinasse application in burned 418 sugarcane systems may prevent further decreases of soil $\mathrm{C}$ stocks (Fig. 8a). There was an increase 419 of approximately $2 \mathrm{Mg} \mathrm{C} \mathrm{ha}^{-1}$, equivalent to $10 \%$, under lower application rates of vinasse in 420 comparison to a burned management without vinasse additions. Under high vinasse application 421 rates, the increase of soil C may be double (average of $0.04 \mathrm{Mg} \mathrm{C} \mathrm{ha}^{-1} \mathrm{yr}^{-1}$ ), when compared with 422 the B management, resulting a difference of approximately $5 \mathrm{Mg} \mathrm{C} \mathrm{ha}^{-1}$ by 2100 . The use of 423 different application rates of vinasse in the UB management (Fig. 8b) had a similar pattern 424 observed under a B management. Nevertheless, under UB management, similar soil C stocks were 425 simulated for 2100 whether receiving low or standard application rates. 


\section{4. Discussion}

4274.1 Effects of vinasse application on soil C

428 Our results suggest that vinasse application can increase soil C stocks, particularly in the top

$42930 \mathrm{~cm}$. This increase may be partly due to enhanced sugarcane biomass production (de Resende et

430 al. 2006) leading to increased organic matter inputs (Araújo et al. 2009; Brandani et al. 2015) and

431 nutrients such as exchangeable K (Zolin et al. 2011). Increased biomass production leads to

432 increased plant litter input which in turn can modify soil quality through improved physical,

433 chemical and biological properties (Jiang et al. 2012; Prado et al. 2013) resulting in more soil C

434 being accumulated (Galdos et al. 2009a). Yield improvement following vinasse application have

435 been observed to be approximately $13 \%$ greater in the first and second cycles of sugarcane

436 plantation (de Resende et al. 2006).

437 The infiltration of vinasse soluble $\mathrm{C}$ and nutrients is likely to be limited to the soil surface

438 layers where more than $80 \%$ of the root system can dominate (Ohashi et al. 2015). In these surface

439 layers the greater availability of nutrients, organic matter and water provided by vinasse may

440 stimulate higher root biomass density by reducing water and nutrient limitation (Smith et al. 2005).

441 The results of Pina et al. (2015) support this assumption with enhanced root growth with vinasse

442 application compared to basic fertilization (only NKP mineral fertiliser) at 0-20 $\mathrm{cm}$ depth. Jiang

443 et al. (2012) report that after three years of vinasse application soil porosity was maintained or

444 even increased with greater aggregation of fine soil particles at 0-30 cm depth, which would allow

445 higher potential root growth. Overall an increased concentration of roots in the topsoil layers after

446 vinasse application might stimulate the accumulation of soil $\mathrm{C}$ through greater root turnover and

447 exudation as well as enhancement of microbial biomass (Navarrete et al. 2015; Pina et al. 2015). 
448 By contrast, lower nutrient availability in the surface layers under no vinasse management may

449 encourage root development in deeper soil resulting in a higher soil C stocks for $60-80 \mathrm{~cm}$ depth.

450 Whilst vinasse application management resulted in higher soil C stocks, this did not translate

451 into a significant soil $\mathrm{C}$ accumulation in specific soil fractions as expected. This might be

452 associated with the labile nature of the $\mathrm{C}$ that vinasse added and potential fast decomposition of it.

453 Greater nutrient availability promoted by vinasse management can increase the soil decomposers

454 community which may easily offset the C added (Carmo et al. 2013; Oliveira et al. 2013; Siqueira

455 Neto et al. 2016). Further, the light-coarse particulate organic matter fraction (i.e. POM $>53 \mu \mathrm{m}$ ),

456 which is chiefly related to inputs from biomass and plant litter, can also show high spatial and

457 seasonal variability (Christensen 1992). Hence, POM may be seen to represent faster C turnover

458 and nutrient cycling in the soil (Gama-Rodrigues \& Gama-Rodrigues 2008) due to its lability,

459 allowing for rapid microbial decomposition. The lack of difference between no vinasse and

460 vinasse-based management in the fractions (specially POM and HF) might be also associated with

461 the recent soil tillage and replanting operation at both sites and potential exposure of the $\mathrm{C}$ added

462 to mineralisation (Paustian et al. 1997; Six et al. 2002).Therefore, although not significant in this

463 study, the trend in soil $\mathrm{C}$ accumulation at $\mathrm{S}+\mathrm{C}$ fraction under vinasse management is an important

464 observation being a potentially stable soil fraction. (Christensen 2001; Lisboa et al. 2009).

465 In general, vinasse application was a beneficial management practice. Its application led to 466 an accumulation of $0.55 \mathrm{Mg} \mathrm{ha}^{-1} \mathrm{yr}^{-1}$ soil $\mathrm{C}$ stock of over 10 years in the topsoil $(0-30 \mathrm{~cm})$ layers.

467 This is more than double of the soil C accumulation found by de Resende et al. (2006) in a related 468 study over 16 years for the top $20 \mathrm{~cm}$ of soil $\left(0.25 \mathrm{Mg} \mathrm{ha}^{-1} \mathrm{yr}^{-1}\right)$. Whilst an accumulation of soil C 469 of $1.1 \mathrm{Mg} \mathrm{ha}^{-1} \mathrm{yr}^{-1}$ was found at 1 metre depth along, there are still uncertainties about the effect 470 of vinasse beneath the topsoil. This overall increase in soil C stocks is an important part of $\mathrm{C}$ 
471 accounting in managed sugarcane plantations, and therefore is important to be considered in any

472 future life-cycle analyses and calculation of payback time.

473

474 4.2 The role of burning cessation on soil $\mathrm{C}$

475 Cessation of burning (UB management) for a 12 year period from 2001 showed higher soil

476 C stock at 30-60 $\mathrm{cm}$ depth but no difference for 0-20 and 70-100 $\mathrm{cm}$ depth. Our findings contrast

477 other studies which report significant differences between burned and unburned management in

478 the topsoil layers only $(0-30 \mathrm{~cm})$ (Cerri et al. 2011; Galdos et al. 2009a; Signor et al. 2014). The

479 legacy effects of past land use change and management at this particular study site may have

480 influenced the observed $\mathrm{C}$ stocks within the soil profile.

481 At the UB management part of the study site, annual cropping was used for 10 years prior to

482 sugarcane plantation. At the other part of the study site where B management was still in place the

483 prior land was under pasture/grassland during the same period. According to Zinn et al. (2005) and

484 Maia et al. (2010), cropland can experience consistently higher losses of C due to continued

485 disturbance, while pasture may either decrease or increase soil $\mathrm{C}$ storage relative to native

486 vegetation areas (Maia et al. 2009). Additionally, in this study sugarcane replanting operation

487 occurred in different times between the sites (2011 and 2008 for UB and B, respectively) and may

488 have homogenised the topsoil layers $(0-20 \mathrm{~cm})$. The replanting operation includes land preparation

489 every 6 years by plowing, disking and in some cases subsoiling prior to planting and fertiliser

490 applications. During replanting, the organic matter in aggregates are exposed due to physical

491 disruption, facilitating increased soil C mineralisation (Paustian et al. 1997; Six et al. 2002), which

492 may result in up to $80 \% \mathrm{C}$ losses in the first 0-20 cm depth (Silva-Olaya et al. 2013). Soil tillage

493 was suggested as factor for the lack of significant differences found in soil C (Galdos et al. 2009a) 
494 or only a modest accumulation rate (Cerri et al. 2011) in topsoil layers. Higher C content may also

495 be found in topsoil under burned management due to the presence of charcoal and ash on the soil

496 surface (Blair 2000). Tillage operations, nonetheless, may have been a primary cause for the higher

497 soil $\mathrm{C}$ stocks recorded in the UB site from 30 to $60 \mathrm{~cm}$ depth through incorporation of the straw

498 deposited in the surface of the soil. According to Thorburn et al. (2011) the amount of straw

499 deposited on the soil surface in the unburned management can reach about 10 to $20 \mathrm{Mg}^{-1}$ with

500 soil under this management often being of higher fertility than soil under burned management

501 (Correia \& Alleoni 2011). Accelerated rates of root turnover due to preferable conditions created

502 by a deeper litter layer (e.g. humidity, temperature and the presence of microorganisms) is

503 expected under unburned management and may help to rationalise the increase in the soil $\mathrm{C}$ stock

504 between 30 and $60 \mathrm{~cm}$. Improved aggregate stability and/or potential additions of other composts

505 to the planting groove (usually done around 40-50 cm depth) may also lead to higher soil $\mathrm{C}$ stocks

506 at these depths. In this study the in deep soil layers $(30-60 \mathrm{~cm})$ after management change from B

507 to UB suggests an increase of soil C stock of approximately $0.7 \mathrm{Mg} \mathrm{ha}^{-1} \mathrm{yr}^{-1}$. This results supports

508 the work of others which suggest a deeper soil layers need to be considered when making

509 conclusions around land use and management impacts on soil C stocks (Keith et al. 2015; Mello

510 et al. 2014).

511 The recent soil tillage might also have influenced the distribution of the soil $\mathrm{C}$ between

512 fractions. Six et al. (1999) emphasised that soil disturbance might alter the aggregate dynamics,

513 increasing the turnover time of SOM and, thus, decreasing the formation of stabilised C fractions.

514 Signor et al. (2014) used the same physical fractionation method as in this study, and showed lower

$515 \mathrm{C}$ concentration in the POM under sugarcane with recent soil disturbance, whereas areas under

516 less disturbance had higher $\mathrm{C}$ concentration, regardless of whether the sugarcane was burned or 
517 unburned. Our results agree with these findings, indicating a somewhat higher $\mathrm{C}$ content in the

518 POM and HF for B compared to UB management where the tillage occurred recently, although

519 they do not differ statistically. The POM is regarded as the main driver responsible for the

520 stabilisation of the macro-aggregates in the soil and has an important role in determining changes

521 of the total C (Tisdall \& Oades 1982). Thus, we suggest that the statistical differences found in

$522 \mathrm{~S}+\mathrm{C}$ in topsoil $(0-20 \mathrm{~cm})$ under the UB management occurred due to decomposition processes at 523 POM prior to soil disturbance i.e. tillage which captured part of this fraction at the $\mathrm{S}+\mathrm{C}$ fraction

524 (Roscoe et al. 2001).

525 An increase of SOM and consequently in soil C stocks, or at least the maintenance of their

526 levels, would lead to higher yields (Pan et al. 2009). Therefore, Brazilian sugarcane under an

527 improved UB management could positively contribute to issues about food security, energy 528 demands and climate changes (Goldemberg et al. 2014; Lal 2004).

4.3 Long-term scenarios of improved sugarcane management

The modelling predictions support empirical data suggesting that improved practices could increase soil $\mathrm{C}$ stocks in the topsoil $(20 \mathrm{~cm})$ over a longer-term. Simulated outcomes $(0-20 \mathrm{~cm})$ for prior land uses and LUC for all sites assessed are similar to other work. For example, Maia et al.

534 (2009) found a similar rate of soil C loss for $0-30 \mathrm{~cm}$ depth, in degraded pastures $\left(-0.28 \mathrm{Mg} \mathrm{ha}^{-1}\right.$ 535 $\mathrm{yr}^{-1}$ ) previously covered by Amazon forest and Cerrado vegetation. Silva-Olaya et al. (2016) in a 536 simulated study with CENTURY, reported that LUC from pasture to sugarcane resulted in losses

537 of soil $\mathrm{C}$ of $-0.19 \mathrm{Mg} \mathrm{ha}^{-1} \mathrm{yr}^{-1}(0-20 \mathrm{~cm})$. For LUC from pasture to cropland (principally soybeans), 538 the annual decrease of soil $\mathrm{C}$ losses found in our simulation is also in aligns with measured results 539 found by Carvalho et al. (2010) and simulated outcomes of Silva-Olaya et al. (2016). 
After the introduction of sugarcane and the improved practices, an increase in soil $\mathrm{C}$ stock

541 was noted in the long-term simulations $(0-20 \mathrm{~cm})$. Transition from NV to V management indicated

542 an upward trend over 22 years (2013-2035) of simulation. It is notable that soils under V

543 management showed a higher potential for $\mathrm{C}$ stocks to increase, albeit at a lower rate as the soils

544 approached an equilibrium C level. Similar measured results were detected in topsoil layers $(0-20$

$545 \mathrm{~cm}$ ) by de Resende et al. (2006), studying 16 years of vinasse plus unburned management, with

546 the authors reporting an increase soil $\mathrm{C}$ stock of around $4 \mathrm{Mg} \mathrm{ha}^{-1}$ over this period. Brandani et al.

547 (2015) also simulated similar outcomes with CENTURY for unburned with additional organic

548 amendments including vinasse. Ultimately, the difference of only 3-3.5 $\mathrm{Mg} \mathrm{ha}^{-1}$ between NV and

$549 \mathrm{~V}$ sites found after 22 years of simulation, indicated that soil $\mathrm{C}$ stocks under vinasse-based

550 management will depend on the balance between increased $\mathrm{C}$ inputs and outputs related to

551 potential change in microbial activity, as well as whether the site is under burned or unburned

552 management. Our results indicate that vinasse application under burned management could be to 553 offset a burning associated decline in soil C stocks (Fig. 8a). Soil C stock was 30\% lower than

554 native vegetation under a burned management, but when combined with vinasse application the

555 difference was only $20 \%$ at high application rates. While vinasse application may have some

556 benefits to increase soil $\mathrm{C}$ stocks, other issues need to be considered such as salinisation and GHG

557 emission (Christofoletti et al. 2013; Oliveira et al. 2013).

558 Long-term simulations showed that unburned management has great potential to increase

559 topsoil $\mathrm{C}$ stocks $(0-20 \mathrm{~cm})$ as well as sugarcane yield (Fig. 7 and Fig. S5, respectively). Over a

560 projected 35 year period (2013-2049), the increase of soil C stock from B to UB management was

561 approximately $0.4 \mathrm{Mg} \mathrm{ha}^{-1} \mathrm{yr}^{-1}$, followed by a slower rate of accumulation $\left(\sim 0.06 \mathrm{Mg} \mathrm{ha}^{-1} \mathrm{yr}^{-1}\right)$ as

562 the equilibrium state for soil C storage was achieved (2050-2100). These results agree with 
563 Razafimbelo et al. (2006) who measured a C accumulation rate of $0.65 \mathrm{Mg} \mathrm{ha}^{-1} \mathrm{yr}^{-1}$ in the topsoil

564 layer $(10 \mathrm{~cm})$ for an unburned area after 6 years (one cycle without replanting operations,

565 ploughing and disking); the authors suggested further research is required to assess the effects of

566 tillage disturbance on replanting sugarcane. Our simulated long-term results indicated that the

567 increase in $\mathrm{C}$ accumulation may be the same for $0-20 \mathrm{~cm}$ depth even taking into consideration

568 tillage every 6 years, during a period of 35 years, i.e. six tillage operations carried out. All

569 simulated long-term perspectives should be considered as scenarios only since as uncertainties

570 around future crop varieties, climatic variation and management options will all impact on the

571 future performance of these bioenergy systems. 


\section{5. Conclusions}

573 In this study we examined the impacts of vinasse application and the cessation of burning

574 on soil C, demonstrating both empirically and with a mechanistic model, potential benefits to soil

$575 \mathrm{C}$ stocks after change in sugarcane management practices. Vinasse application might be the most

576 available first step to mitigate losses of soil C stocks in burned sugarcane plantations. Although

577 this study provides a site specific approach, the outcomes build on the payback time calculation

578 for ethanol production by Mello et al. (2014). This is particularly relevant for the State of São

579 Paulo being responsible for approximately $60 \%$ of Brazil's production and where such

580 management changes are being widely adopted (UNICA 2016). However, further studies are

581 highly required, particularly considering Brazil's central region where the sugarcane expansion is

582 widely occurring (Adami et al. 2012) as well as taking into account other soil types, crop varieties, 583 management practices and climate conditions.

\section{Acknowledgments}

586 The authors thank São Luiz mill to provide the areas for the study, and also Adriana M. Silva-

587 Olaya for the suggestions in the modelling approaches and Peter A. Henrys (CEH) for useful 588 discussions and input on statistical approaches. 
589

590

591

592

593

594

595

596

597

598

599

600

601

602

603

604

605

606

607

608

609

610

611

612

613

614

615

616

617

618

619

620

621

622

623

624

625

626

627

628

629

630

631

\section{References}

Adami M, Rudorff BFT, Freitas RM, Aguiar DA, Sugawara LM, and Mello MP. 2012. Remote Sensing Time Series to Evaluate Direct Land Use Change of Recent Expanded Sugarcane Crop in Brazil. Sustainability 4:574-585. 10.3390/su4040574

Anderson JN, and Ingram JSI. 1989. Tropical Soil biology and fertility: a handbook of methods. . Wallingford: CAB International.

Araújo ASF, Leite LFC, Santos VB, and Carneiro RFV. 2009. Soil Microbial Activity in Conventional and Organic Agricultural Systems. Sustainability 1:268-276. $10.3390 /$ su1020268

Batlle-Bayer L, Batjes NH, and Bindraban PS. 2010. Changes in organic carbon stocks upon land use conversion in the Brazilian Cerrado: A review. Agriculture, Ecosystems \& Environment 137:47-58. 10.1016/j.agee.2010.02.003

Blair N. 2000. Impact of cultivation and sugar-cane green trash management on carbon fractions and aggregate stability for a Chromic Luvisol in Queensland, Australia. Soil and Tillage Research 55:183-191. http://dx.doi.org/10.1016/S0167-1987(00)00113-6

Bordin I, Neves CSVJ, Medina CdC, Santos JCFd, Torres E, and Urquiaga S. 2008. Matéria seca, carbono e nitrogênio de raízes de soja e milho em plantio direto e convencional. Pesquisa Agropecuária Brasileira 43:1785-1792.

Brandani CB, Abbruzzini TF, Conant RT, and Cerri CEP. 2016. Soil organic and organomineral fractions as indicators of the effects of land management in conventional and organic sugar cane systems. Soil Research. 10.1071/sr15322

Brandani CB, Abbruzzini TF, Williams S, Easter M, Pellegrino Cerri CE, and Paustian K. 2015. Simulation of management and soil interactions impacting SOC dynamics in sugarcane using the CENTURY Model. GCB Bioenergy 7:646-657. 10.1111/gcbb.12175

Cançado JED, Saldiva PHN, Pereira LAA, Lara LBLS, Artaxo P, Martinelli LA, Arbex MA, Zanobetti A, and Braga ALF. 2006. The Impact of Sugar Cane-Burning Emissions on the Respiratory System of Children and the Elderly. Environmental Health Perspectives 114:725-729. 10.1289/ehp.8485

Carmo JBd, Filoso S, Zotelli LC, de Sousa Neto ER, Pitombo LM, Duarte-Neto PJ, Vargas VP, Andrade CA, Gava GJC, Rossetto R, Cantarella H, Neto AE, and Martinelli LA. 2013. Infield greenhouse gas emissions from sugarcane soils in Brazil: effects from synthetic and organic fertilizer application and crop trash accumulation. GCB Bioenergy 5:267-280. 10.1111/j.1757-1707.2012.01199.x

Carvalho JLN, Raucci GS, Cerri CEP, Bernoux M, Feigl BJ, Wruck FJ, and Cerri CC. 2010. Impact of pasture, agriculture and crop-livestock systems on soil C stocks in Brazil. Soil and Tillage Research 110:175-186. 10.1016/j.still.2010.07.011

Cerri CC, Galdos MV, Maia SMF, Bernoux M, Feigl BJ, Powlson D, and Cerri CEP. 2011. Effect of sugarcane harvesting systems on soil carbon stocks in Brazil: an examination of existing data. European Journal of Soil Science 62:23-28. 10.1111/j.1365-2389.2010.01315.x

Cerri CEP, Easter M, Paustian K, Killian K, Coleman K, Bernoux M, Falloon P, Powlson DS, Batjes N, Milne E, and Cerri CC. 2007. Simulating SOC changes in 11 land use change chronosequences from the Brazilian Amazon with RothC and Century models. Agriculture, Ecosystems \& Environment 122:46-57. 10.1016/j.agee.2007.01.007 
632 Cerri CEP, Galdos MV, Carvalho JLN, Feigl BJ, and Cerri CC. 2013. Quantifying soil carbon 633 stocks and greenhouse gas fluxes in the sugarcane agrosystem: point of view. Scientia 634

635

636

637

638

639

640

641

642

643

644

645

646

647

648

649

650

651

652

653

654

655

656

657

658

659

660

661

662

663

664

665

666

667

668

669

670

671

672

673

674

675

676 Agricola 70:361-368.

Cerri CEP, Paustian K, Bernoux M, Victoria RL, Melillo JM, and Cerri CC. 2004. Modeling changes in soil organic matter in Amazon forest to pasture conversion with the Century model. Global Change Biology 10:815-832. 10.1111/j.1365-2486.2004.00759.x

Cherubin MR, Franco ALC, Cerri CEP, Oliveira DMdS, Davies CA, and Cerri CC. 2015. Sugarcane expansion in Brazilian tropical soils-Effects of land use change on soil chemical attributes. Agriculture, Ecosystems \& Environment 211:173-184. 10.1016/j.agee.2015.06.006

Christensen BT. 1992. Physical fractionation of soil and organic matter in primary particle size and density separates. Advances in Soil Science 20.

Christensen BT. 2001. Physical fractionation of soil and structural and functional complexity in organic matter turnover. European Journal of Soil Science 52:345-353. 10.1046/j.13652389.2001.00417.x

Christofoletti CA, Escher JP, Correia JE, Marinho JF, and Fontanetti CS. 2013. Sugarcane vinasse: environmental implications of its use. Waste Manag 33:2752-2761. 10.1016/j.wasman.2013.09.005

Có Júnior C, Marques MO, and Tasso Júnior LC. 2008. Efeito residual de quatro aplicações anuais de lodo de esgoto e vinhaça na qualidade tecnológica da cana-de-açúcar. Engenharia Agrícola 28:196-203.

Cong R, Wang X, Xu M, Ogle SM, and Parton WJ. 2014. Evaluation of the CENTURY model using long-term fertilization trials under corn-wheat cropping systems in the typical croplands of China. PLoS One 9:e95142. 10.1371/journal.pone.0095142

Correia BL, and Alleoni LRF. 2011. Conteúdo de carbono e atributos químicos de Latossolo sob cana-de-açúcar colhida com e sem queima. Pesquisa Agropecuária Brasileira 46:944-952.

Cunha GdM, Gama-Rodrigues AC, Gama-Rodrigues EF, and Velloso ACX. 2009. Biomassa e estoque de carbono e nutrientes em florestas montanas da mata atlântica na região norte do estado do Rio de Janeiro. Revista Brasileira de Ciência do Solo 33:1175-1185.

Davis SC, Boddey RM, Alves BJR, Cowie AL, George BH, Ogle SM, Smith P, van Noordwijk $\mathrm{M}$, and van Wijk MT. 2013. Management swing potential for bioenergy crops. $G C B$ Bioenergy 5:623-638. 10.1111/gcbb.12042

de Resende AS, Xavier RP, de Oliveira OC, Urquiaga S, Alves BJR, and Boddey RM. 2006. Longterm Effects of Pre-harvest Burning and Nitrogen and Vinasse Applications on Yield of Sugar Cane and Soil Carbon and Nitrogen Stocks on a Plantation in Pernambuco, N.E. Brazil. Plant and Soil 281:339-351. 10.1007/s11104-005-4640-y

Ellert BH, and Bettany JR. 1995. Calculation of organic matter and nutrients stored in soils under contrasting management regimes. Canadian Journal of Soil Science 75:529-538. 10.4141/cjss95-075

EMBRAPA. 1997. Manual de método de analise de solo. Rio de Janeiro: EMBRAPA, CNPS.

FAO. 2014. World Reference Base for Soil Resources 2014. International Soil Classification System for Naming Soils and Creating Legends for Soil Maps. In: Report WSR, editor. Rome. p 106.

Fargione J, Hill J, Tilman D, Polasky S, and Hawthorne P. 2008. Land clearing and the biofuel carbon debt. Science 319:1235-1238. 10.1126/science.1152747 
677 Finoto EL, Bolonhezi D, Soarea MBB, and Martins ALM. 2012. Produção de soja RR e ocorrência

678

679

680

681

682

683

684

685

686

687

688

689

690

691

692

693

694

695

696

697

698

699

700

701

702

703

704

705

706

707

708

709

710

711

712

713

714

715

716

717

718

719

720

721 de plantas daninhas em áreas de reforma de cana crua com diferentes manejos na destruição da soqueira. Pesquisa \& Tecnologia 2:1-9.

Franco AL, Cherubin MR, Pavinato PS, Cerri CE, Six J, Davies CA, and Cerri CC. 2015. Soil carbon, nitrogen and phosphorus changes under sugarcane expansion in Brazil. Sci Total Environ 515-516:30-38. 10.1016/j.scitotenv.2015.02.025

Fronzalia T. 2007. Cana-de-açúcar: expansão alarmante. São Paulo: Instituto de Economia Agrícola. Available at http://www.iea.sp.gov.br/out/verTexto.php?codTexto=8905 (accessed 2nd April 2015 2015).

Fuess LT, and Garcia ML. 2014. Implications of stillage land disposal: a critical review on the impacts of fertigation. $J$ Environ Manage 145:210-229. 10.1016/j.jenvman.2014.07.003

Galdos M, Cavalett O, Seabra JEA, Nogueira LAH, and Bonomi A. 2013. Trends in global warming and human health impacts related to Brazilian sugarcane ethanol production considering black carbon emissions. Applied Energy 104:576-582. 10.1016/j.apenergy.2012.11.002

Galdos MV, Cerri CC, and Cerri CEP. 2009a. Soil carbon stocks under burned and unburned sugarcane in Brazil. Geoderma 153:347-352. 10.1016/j.geoderma.2009.08.025

Galdos MV, Cerri CC, Cerri CEP, Paustian K, and Van Antwerpen R. 2009b. Simulation of Soil Carbon Dynamics under Sugarcane with the CENTURY Model. Soil Science Society of America Journal 73:802. 10.2136/sssaj2007.0285

Galdos MV, Cerri CC, Cerri CEP, Paustian K, and Van Antwerpen R. 2009c. Simulation of sugarcane residue decomposition and aboveground growth. Plant and Soil 326:243-259. 10.1007/s11104-009-0004-3

Galdos MV, Cerri CC, Lal R, Bernoux M, Feigl B, and Cerri CEP. 2010. Net greenhouse gas fluxes in Brazilian ethanol production systems. GCB Bioenergy 2:37-44. 10.1111/j.17571707.2010.01037.x

Gama-Rodrigues EF, and Gama-Rodrigues AC. 2008. Biomassa microbiana e ciclagem de nutrientes In: Santos GA, Silva LS, Canellas LP, Camargo FO. (Ed.). Fundamentos da matéria orgânica do solo: ecossistemas tropicais e subtropicais.

Goldemberg J, Mello FFC, Cerri CEP, Davies CA, and Cerri CC. 2014. Meeting the global demand for biofuels in 2021 through sustainable land use change policy. Energy Policy 69:14-18. 10.1016/j.enpol.2014.02.008

Guo LB, and Gifford RM. 2002. Soil carbon stocks and land use change: a meta analysis. Global Change Biology 8:345-360. 10.1046/j.1354-1013.2002.00486.x

INMET. 2016. Instituto Nacional De Meteorologia. Clima, Estacao e Dados, Dados Historicos Available at http://www.inmet.gov.br/portal/index.php? $r=b d$ mep/bdmep.

Jiang Z-P, Li Y-R, Wei G-P, Liao Q, Su T-M, Meng Y-C, Zhang H-Y, and Lu C-Y. 2012. Effect of Long-Term Vinasse Application on Physico-chemical Properties of Sugarcane Field Soils. Sugar Tech 14:412-417. 10.1007/s12355-012-0174-9

Keith AM, Henrys PA, Rowe RL, and McNamara NP. 2016. Technical note: A bootstrapped LOESS regression approach for comparing soil depth profiles. Biogeosciences 13:38633868. 10.5194/bg-13-3863-2016

Keith AM, Rowe RL, Parmar K, Perks MP, Mackie E, Dondini M, and McNamara NP. 2015. Implications of land-use change to Short Rotation Forestry in Great Britain for soil and biomass carbon. GCB Bioenergy 7:541-552. 10.1111/gcbb.12168 
722

723

724

725

726

727

728

729

730

731

732

733

734

735

736

737

738

739

740

741

742

743

744

745

746

747

748

749

750

751

752

753

754

755

756

757

758

759

760

761

762

763

764

765

Laime EMO, Fernandes PD, Oliveira DCS, and Freire EA. 2011. Possibilidades Tecnológicas para a Destinação da Vinhaça: Uma Revisão. Revista Trópica - Ciências Agrárias e Biológicas 5:16-29.

Lal R. 2004. Soil carbon sequestration impacts on global climate change and food security. Science 304:1623-1627. 10.1126/science. 1097396

Lilienfein J, and Wilcke W. 2003. Element storage in native, agri-, and silvicultural ecosystems of the Brazilian savanna. Plant and Soil 254:425-442. 10.1023/a:1025579932395

Lisboa CC, Conant RT, Haddix ML, Cerri CEP, and Cerri CC. 2009. Soil Carbon Turnover Measurement by Physical Fractionation at a Forest-to-Pasture Chronosequence in the Brazilian Amazon. Ecosystems 12:1212-1221. 10.1007/s10021-009-9288-7

Maia SMF, Ogle SM, Cerri CC, and Cerri CEP. 2010. Changes in soil organic carbon storage under different agricultural management systems in the Southwest Amazon Region of Brazil. Soil and Tillage Research 106:177-184. 10.1016/j.still.2009.12.005

Maia SMF, Ogle SM, Cerri CEP, and Cerri CC. 2009. Effect of grassland management on soil carbon sequestration in Rondônia and Mato Grosso states, Brazil. Geoderma 149:84-91. 10.1016/j.geoderma.2008.11.023

Mello FFC, Cerri CEP, Davies CA, Holbrook NM, Paustian K, Maia SMF, Galdos MV, Bernoux M, and Cerri CC. 2014. Payback time for soil carbon and sugar-cane ethanol. Nature Climate Change 4:605-609. 10.1038/nclimate2239

Navarrete AA, Diniz TR, Braga LPP, Silva GGZ, Franchini JC, Rossetto R, Edwards RA, and Tsai SM. 2015. Multi-Analytical Approach Reveals Potential Microbial Indicators in Soil for Sugarcane Model Systems. PLoS One 10:e0129765. 10.1371/journal.pone.0129765

Nelson DW, and Sommers LE. 1996. Total carbon, organic carbon, and organic matter. In: Page AL, Miller RH, and Keeney DR, eds. Methods of soil analysis Part 2 2: Madison: ASA, 961-1010.

OECD/FAO. 2013. Biofuels, in OECD-FAO Agricultural Outlook 2013: OECD Publishing.

Ohashi AYP, Pires RCdM, Ribeiro RV, and Silva ALBdO. 2015. Root growth and distribution in sugarcane cultivars fertigated by a subsurface drip system. Bragantia 74:131-138. 10.1590/1678-4499.0295

Oliveira BG, Carvalho JLN, Cerri CEP, Cerri CC, and Feigl BJ. 2013. Soil greenhouse gas fluxes from vinasse application in Brazilian sugarcane areas. Geoderma 200-201:77-84. 10.1016/j.geoderma.2013.02.005

Oliveira BG, Nunes Carvalho JL, Pellegrino Cerri CE, Cerri CC, and Feigl BJ. 2015. Greenhouse gas emissions from sugarcane vinasse transportation by open channel: a case study in Brazil. Journal of Cleaner Production 94:102-107. 10.1016/j.jclepro.2015.02.025

Pan G, Smith P, and Pan W. 2009. The role of soil organic matter in maintaining the productivity and yield stability of cereals in China. Agriculture, Ecosystems \& Environment 129:344348. 10.1016/j.agee.2008.10.008

Parton WJ, and Rasmussen PE. 1994. Long-Term Effects of Crop Management in Wheat-Fallow: II. CENTURY Model Simulations. Soil Science Society of America Journal 58:530-536. 10.2136/sssaj1994.03615995005800020040x

Parton WJ, Schimel DS, Cole CV, and Ojima DS. 1987. Analysis of Factors Controlling Soil Organic Matter Levels in Great Plains Grasslands1. Soil Science Society of America Journal 51:1173-1179. 10.2136/sssaj1987.03615995005100050015x 
766

767

768

769

770

771

772

773

774

775

776

777

778

779

780

781

782

783

784

785

786

787

788

789

790

791

792

793

794

795

796

797

798

799

800

801

802

803

804

805

806

807

808

809

810

811

Paustian K, Collins HP, and Paul EA. 1997. Management controls on soil carbon. In: Paul EA, Paustian K, Elliott ET, and Cole CV, eds. Soil organic matter in temperate Agroecosystems - Long-term experiments in North America, 15-49.

Pina JC, Bono JAM, Oliveira AKMd, Rufino RdS, and Amorim DO. 2015. Organic residues on rooting and yield of sugarcane in Typic Quartzipsamments soil. Revista Brasileira de Engenharia Agrícola e Ambiental 19:650-655. 10.1590/1807-1929/agriambi.v19n7p650655

Prado RdM, Caione G, and Campos CNS. 2013. Filter Cake and Vinasse as Fertilizers Contributing to Conservation Agriculture. Applied and Environmental Soil Science 2013:1-8. 10.1155/2013/581984

R Development Core Team. 2018. R: A language and environment to statistical computing. Vienna, Austria: R Foundation for Statistical Computing.

Razafimbelo T, Barthès B, Larré-Larrouy M-C, Luca EFD, Laurent J-Y, Cerri CC, and Feller C. 2006. Effect of sugarcane residue management (mulching versus burning) on organic matter in a clayey Oxisol from southern Brazil. Agriculture, Ecosystems \& Environment 115:285-289. 10.1016/j.agee.2005.12.014

Roscoe R, Buurman P, Velthorst EJ, and Vasconcellos CA. 2001. Soil organic matter dynamics in density and particle size fractions as revealed by the $13 \mathrm{C} / 12 \mathrm{C}$ isotopic ratio in a Cerrado's oxisol. Geoderma 104:185-202. http://dx.doi.org/10.1016/S0016-7061(01)00080-5

Rowe RL, Keith AM, Elias D, Dondini M, Smith P, Oxley J, and McNamara NP. 2016. Initial soil $\mathrm{C}$ and land-use history determine soil $\mathrm{C}$ sequestration under perennial bioenergy crops. GCB Bioenergy 8:1046-1060. 10.1111/gcbb.12311

Signor D, Zani CF, Paladini AA, Deon MDI, and Cerri CEP. 2014. Estoques de carbono e qualidade da matéria orgânica do solo em áreas cultivadas com cana-de-açúcar. Revista Brasileira de Ciência do Solo 38:1402-1410.

Silva-Olaya AM, Cerri CEP, La Scala Jr N, Dias CTS, and Cerri CC. 2013. Carbon dioxide emissions under different soil tillage systems in mechanically harvested sugarcane. Environmental Research Letters 8:015014. 10.1088/1748-9326/8/1/015014

Silva-Olaya AM, Cerri CEP, Williams S, Cerri CC, Davies CA, and Paustian K. 2016. Modelling SOC response to land use change and management practices in sugarcane cultivation in South-Central Brazil. Plant and Soil. 10.1007/s11104-016-3030-y

Siqueira Neto M, Galdos MV, Feigl BJ, Cerri CEP, and Cerri CC. 2016. Direct N2O emission factors for synthetic $\mathrm{N}$-fertilizer and organic residues applied on sugarcane for bioethanol production in Central-Southern Brazil. GCB Bioenergy 8:269-280. 10.1111/gcbb.12251

Six J, Elliott ET, and Paustian K. 1999. Aggregate and Soil Organic Matter Dynamics under Conventional and No-Tillage Systems. Soil Science Society of America Journal 63:13501358. 10.2136/sssaj1999.6351350x

Six J, Feller C, Denef K, Ogle SM, de Moraes JC, and Albrecht A. 2002. Soil organic matter, biota and aggregation in temperate and tropical soils - Effects of no-tillage. Agronomie 22:755775. 10.1051/agro:2002043

Smith DM, Inman-Bamber NG, and Thorburn PJ. 2005. Growth and function of the sugarcane root system. Field Crops Research 92:169-183. 10.1016/j.fcr.2005.01.017

Smith P, Davies CA, Ogle S, Zanchi G, Bellarby J, Bird N, Boddey RM, McNamara NP, Powlson D, Cowie A, Noordwijk M, Davis SC, Richter DDEB, Kryzanowski L, Wijk MT, Stuart J, Kirton A, Eggar D, Newton-Cross G, Adhya TK, and Braimoh AK. 2012. Towards an integrated global framework to assess the impacts of land use and management change on 
812

813

814

815

816

817

818

819

820

821

822

823

824

825

826

827

828

829

830

831

832

833

834

835

836

837

838

839

840

841

842

843

844

845

846

847

848 soil carbon: current capability and future vision. Global Change Biology 18:2089-2101. 10.1111/j.1365-2486.2012.02689.x

Smith P, Smith JU, Powlson DS, Mcgill WB, Arah JRM, Chertvoc OG, Coleman K, Franko U, Frolking S, Jenkinson DS, Jensen LS, Kelly RH, Klein-Gunnewiek H, Komarov AS, Li C, Molina JAE, Mueller T, Parton WJ, Thornley JHM, and Whitmore AP. 1997. A comparison of the performance of nine soil organic matter models using datasets from seven long-term experiments. Geoderma 81:153-225.

Thorburn PJ, Biggs JS, Attard SJ, and Kemei J. 2011. Environmental impacts of irrigated sugarcane production: Nitrogen lost through runoff and leaching. Agriculture, Ecosystems \& Environment 144:1-12. 10.1016/j.agee.2011.08.003

Tisdall JM, and Oades JM. 1982. Organic matter and water-stable aggregates in soils. Journal of Soil Science 33:141-163. 10.1111/j.1365-2389.1982.tb01755.x

UNICA. 2016. Acompanhamento da safra atual na região centro-sul. Acompanhamento quinzenal: Posição até 16/10/2016. São Paulo.

Vallis I, Parton WJ, Keating BA, and Wood AW. 1996. Simulation of the effects of trash and N fertilizer management on soil organic matter levels and yields of sugarcane. Soil and Tillage Research 38:115-132. http://dx.doi.org/10.1016/0167-1987(96)01014-8

Vieira SA, Alves LF, Duarte-Neto PJ, Martins SC, Veiga LG, Scaranello MA, Picollo MC, Camargo PB, do Carmo JB, Neto ES, Santos FA, Joly CA, and Martinelli LA. 2011. Stocks of carbon and nitrogen and partitioning between above- and belowground pools in the Brazilian coastal Atlantic Forest elevation range. Ecol Evol 1:421-434. 10.1002/ece3.41

Walter A, Dolzan P, Quilodrán O, de Oliveira JG, da Silva C, Piacente F, and Segerstedt A. 2011. Sustainability assessment of bio-ethanol production in Brazil considering land use change, GHG emissions and socio-economic aspects. Energy Policy 39:5703-5716. 10.1016/j.enpol.2010.07.043

Walter A, Galdos MV, Scarpare FV, Leal MRLV, Seabra JEA, da Cunha MP, Picoli MCA, and de Oliveira COF. 2014. Brazilian sugarcane ethanol: developments so far and challenges for the future. Wiley Interdisciplinary Reviews: Energy and Environment 3:70-92. 10.1002/wene. 87

Walter K, Don A, and Flessa H. 2015. No general soil carbon sequestration under Central European short rotation coppices. GCB Bioenergy 7:727-740. 10.1111/gcbb.12177

Zinn YL, Lal R, and Resck DVS. 2005. Changes in soil organic carbon stocks under agriculture in Brazil. Soil and Tillage Research 84:28-40. http://dx.doi.org/10.1016/j.still.2004.08.007

Zolin CA, Paulino J, Bertonha A, Freitas PSLd, and Folegatti MV. 2011. Estudo exploratório do uso da vinhaça ao longo do tempo: I. Características do solo. Revista Brasileira de Engenharia Agrícola e Ambiental 15:22-28. 
Figure 1 (on next page)

Timeline of land use and management changes at each site assessed A) No Vinasse to Vinasse, B) Burned to Unburned 
A) No Vinasse (NV) to Vinasse (V)

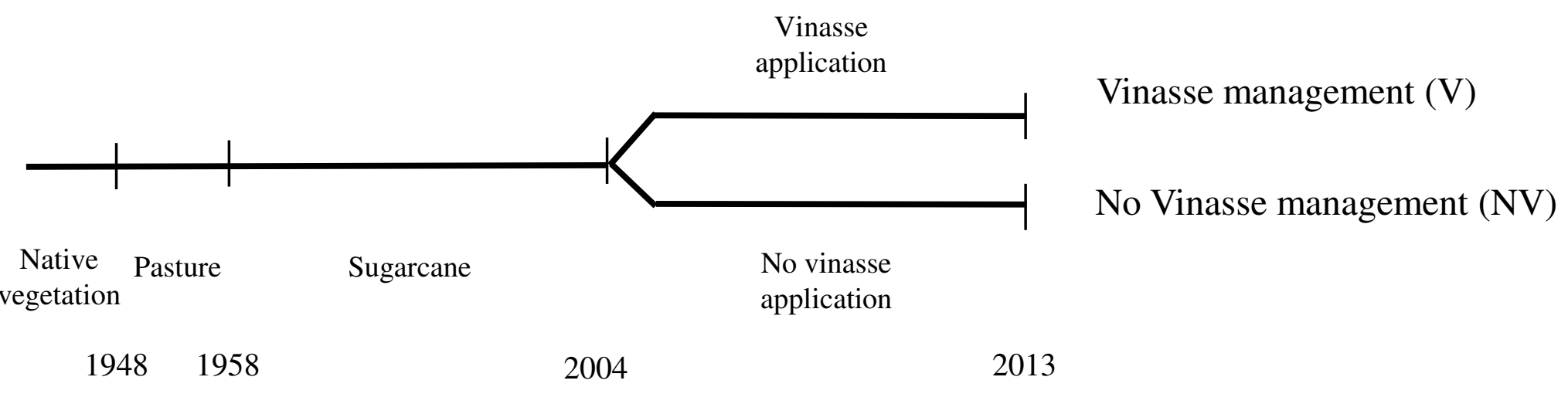

B) Burned (B) to Unburned (UB)

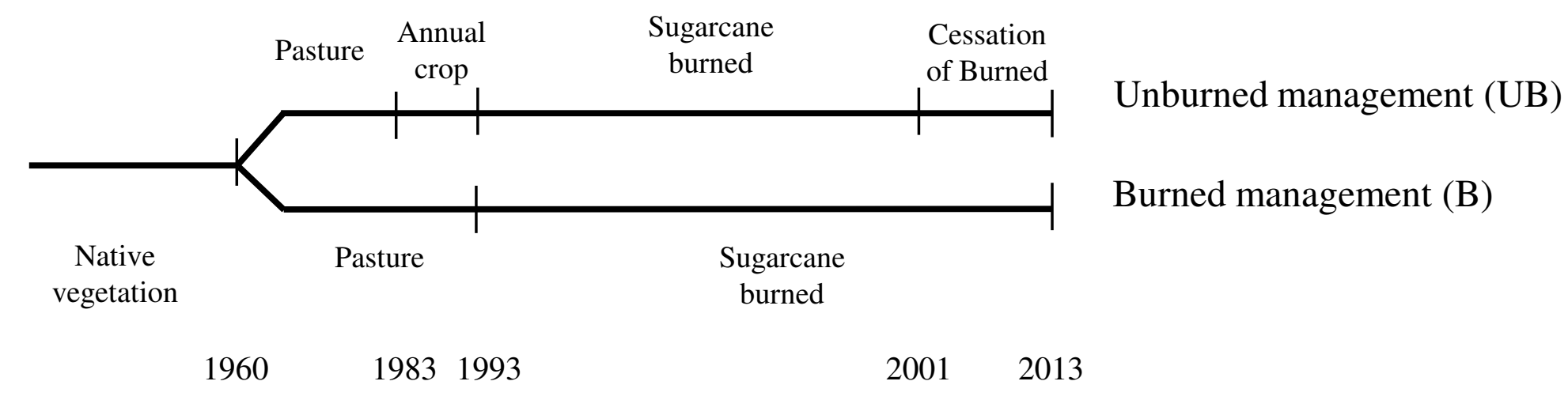


Figure 2 (on next page)

Soil C stock (Mg ha-1) between $0-100 \mathrm{~cm}$ depth in No Vinasse and Vinasse land management systems

No Vinasse (NV; filled circles), Vinasse (V; empty triangles). Dashed lines represent upper and lower bounds of $95 \%$ confidence intervals from bootstrapped $(n=1000)$ loess regressions of combined NV and V data; solid lines represent loess regression of soil C stocks in $\mathrm{V}$ only, where the line sits outside the confidence interval it can be inferred that $N V$ and $V$ are significantly different 


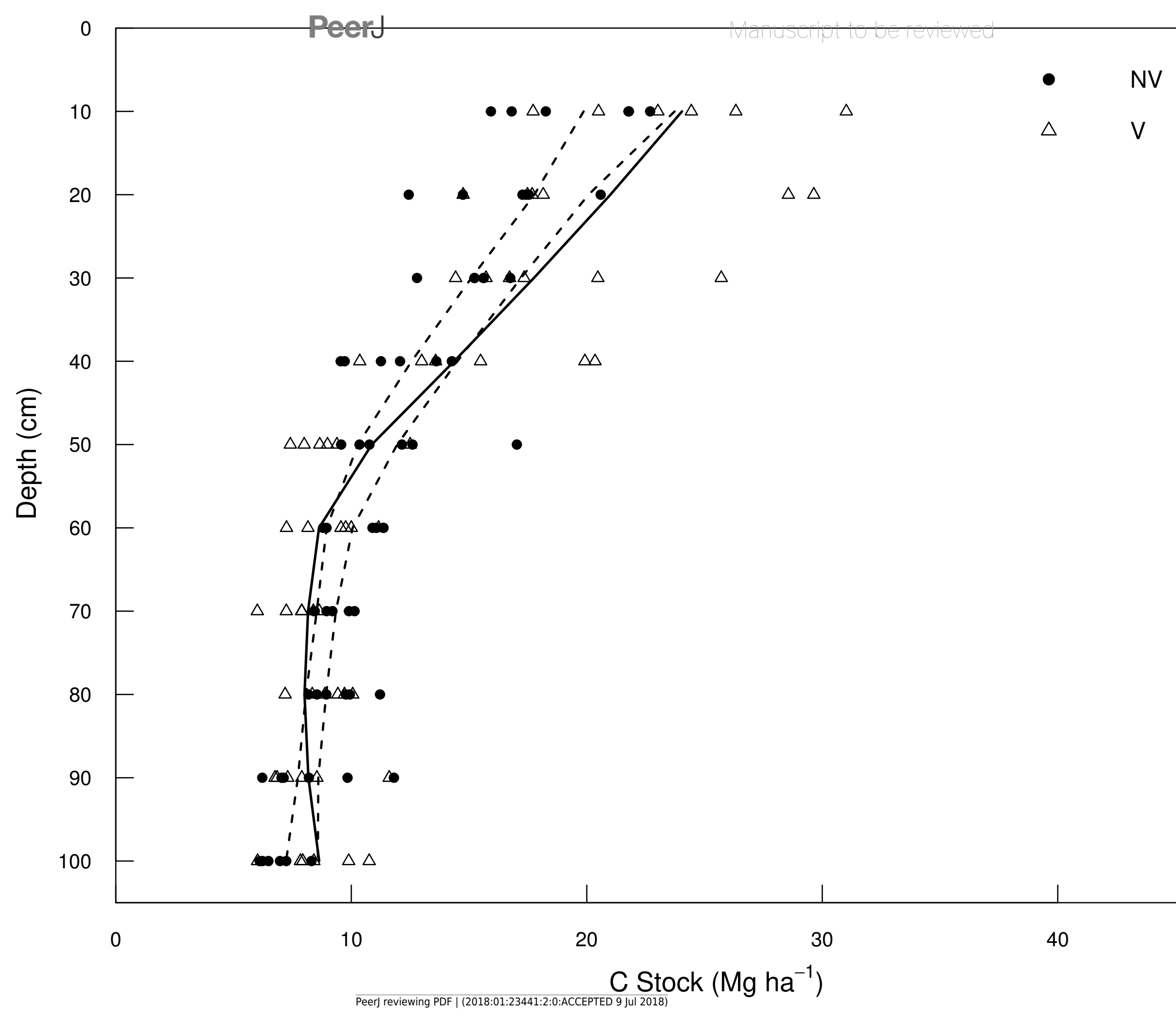


Figure 3 (on next page)

Soil C stock ( $\mathrm{Mg} \mathrm{ha}^{-1}$ ) between $0-100 \mathrm{~cm}$ depth in Burned and Unburned land management systems

Burned ( $B$; filled circles), Unburned (UB; empty triangles). Dashed lines represent upper and lower bounds of $95 \%$ confidence intervals from bootstrapped $(n=1000)$ loess regressions of combined B and UB data; solid lines represents loess regression of soil C stocks in UB only, where the line sits outside the confidence interval it can be inferred that $B$ and UB are significantly different 


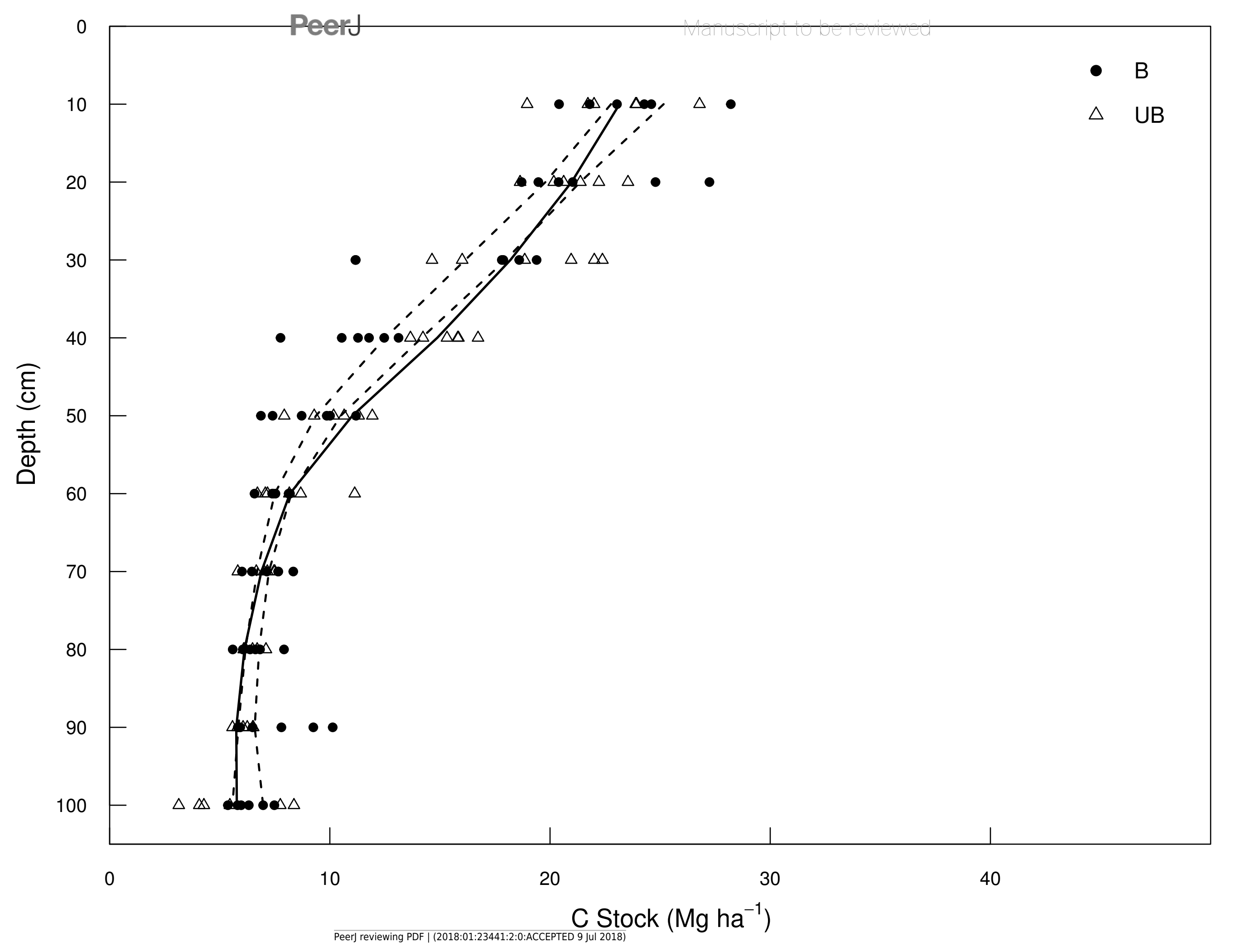


Figure 4 (on next page)

Carbon concentration ( $\mathrm{g} \mathrm{Kg}^{-1}$ soil) in particulate organic matter, heavy and Silt+Clay soil fractions for No Vinasse and Vinasse application managements

a) Particulate organic matter (POM $>53 \mu \mathrm{m}$ ), b) heavy (HF $>53 \mu \mathrm{m}$ ), c) Silt+Clay ( $+\mathrm{C}<53$

$\mu m)$, No Vinasse (NV), Vinasse (V). Top means $0-20 \mathrm{~cm}$ depth. Vertical bars show \pm 1

standard error $(n=3)$, no vertical bars $(n=1)$ 

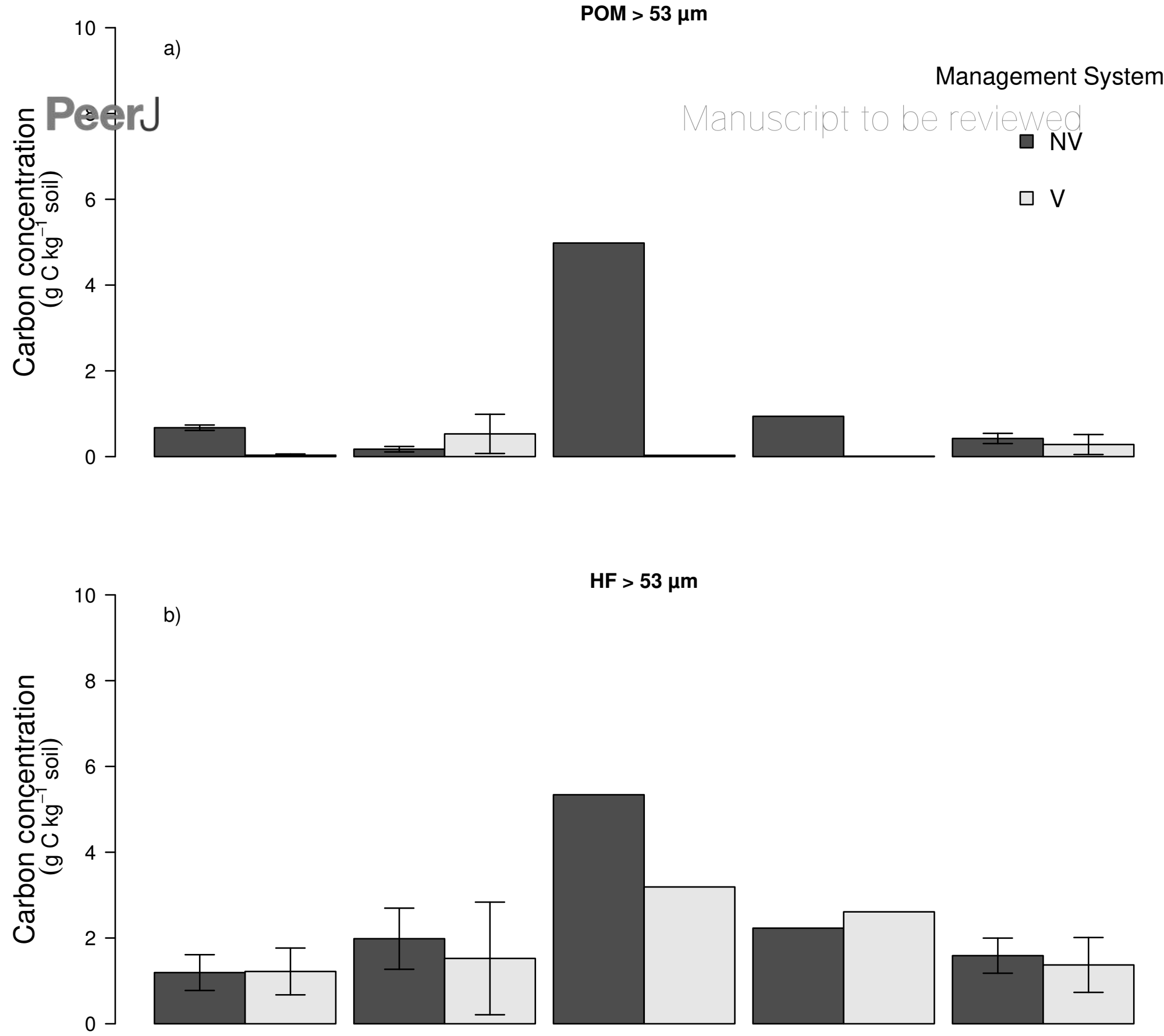

$\mathrm{HF}>53 \mu \mathrm{m}$

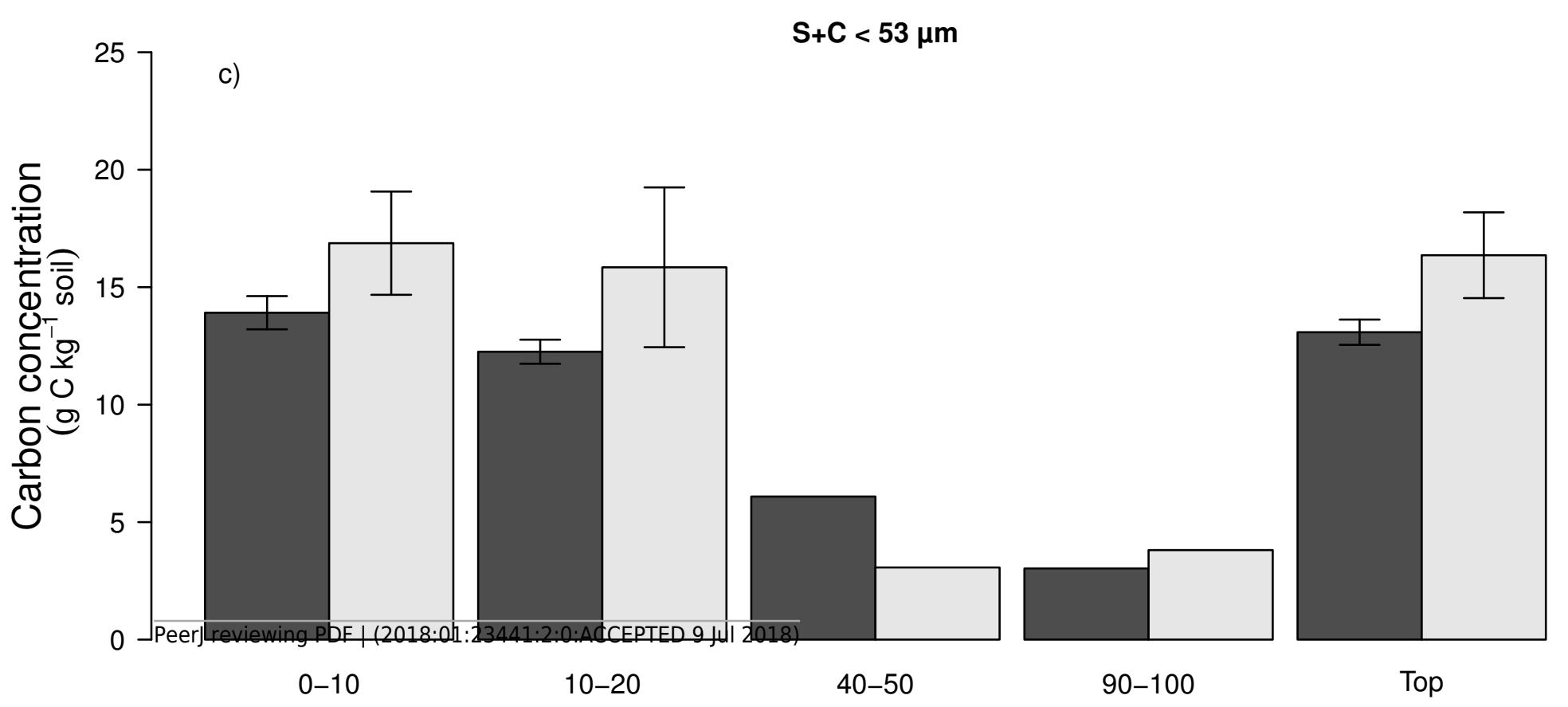


Figure $\mathbf{5}$ (on next page)

Carbon concentration ( $\mathrm{g} \mathrm{C} \mathrm{kg}^{-1} \mathrm{soil}$ ) in the particulate organic matter, heavy and Silt+Clay soil fractions for Burned and Unburned management

a) Particulate organic matter (POM $>53 \mu \mathrm{m}$ ), b) heavy (HF $>53 \mu \mathrm{m}$ ), c) Silt+Clay ( $+\mathrm{C}<53$ $\mu \mathrm{m})$, Burned (B), Unburned (UB). Top means $0-20 \mathrm{~cm}$ depth. Vertical bars show \pm 1 standard error $(n=3)$, no vertical bars $(n=1)$. Asterisk denote significant difference between land management systems $(P<0.05)$ 

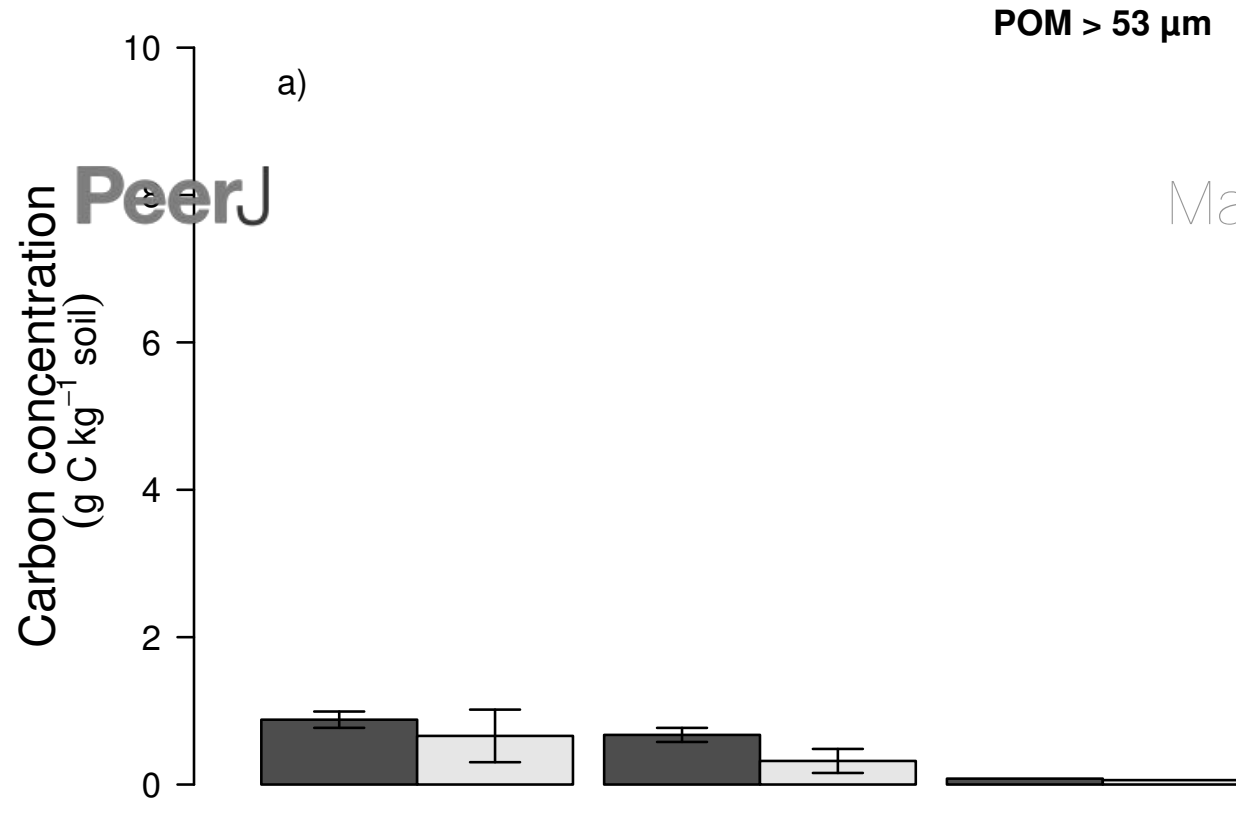

a)

Management System

Manuscript to be reviewed

$\square \mathrm{B}$

$\square$ UB

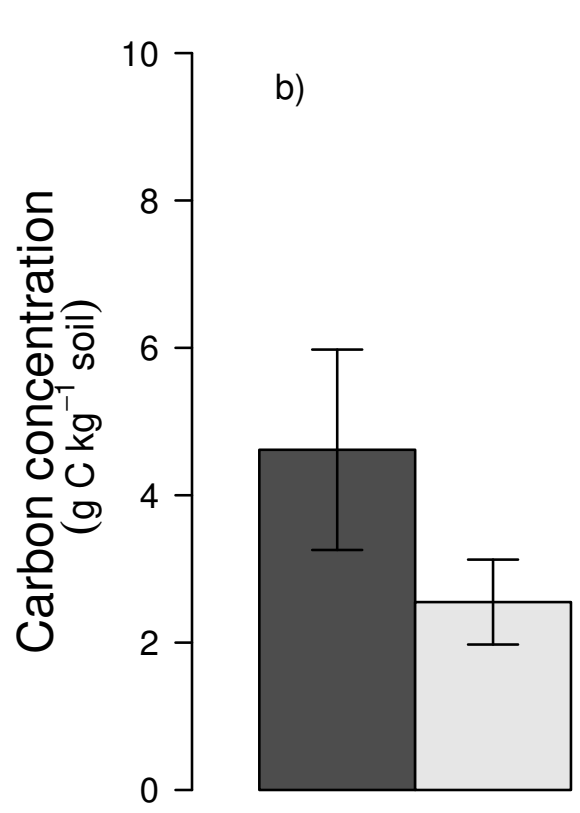

HF $>53 \mu \mathrm{m}$
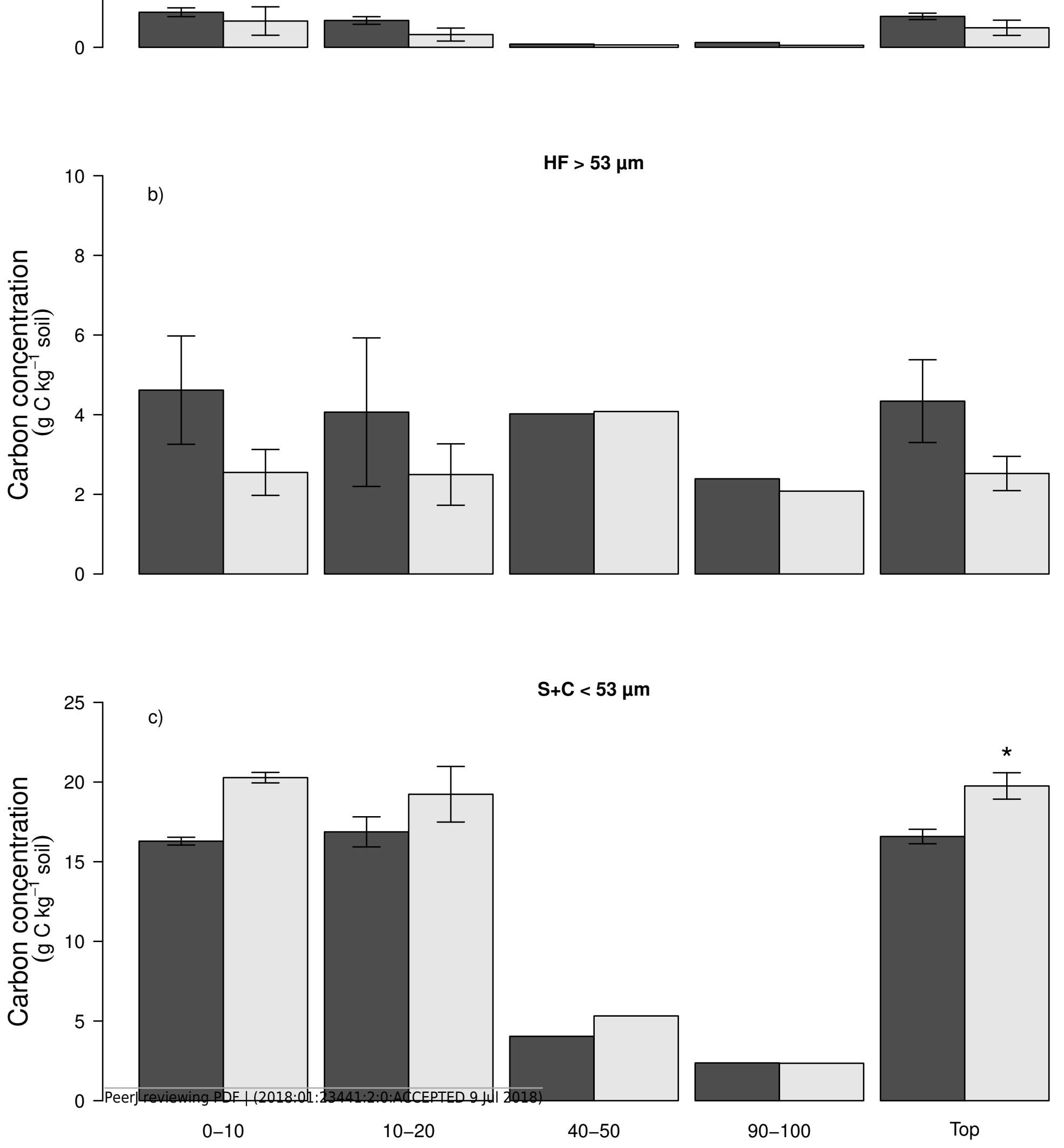
Figure 6 (on next page)

Simulated and measured results for soil $C$ stock $(0-20 \mathrm{~cm})$ under different sugarcane management systems and native vegetation

No vinasse (NV), Vinasse (V), Burned (B), Unburned (UB), Native vegetation ( $F$, as measured

by Franco et al., 2015). Vertical bars show \pm 1 standard error $(n=12)$ 


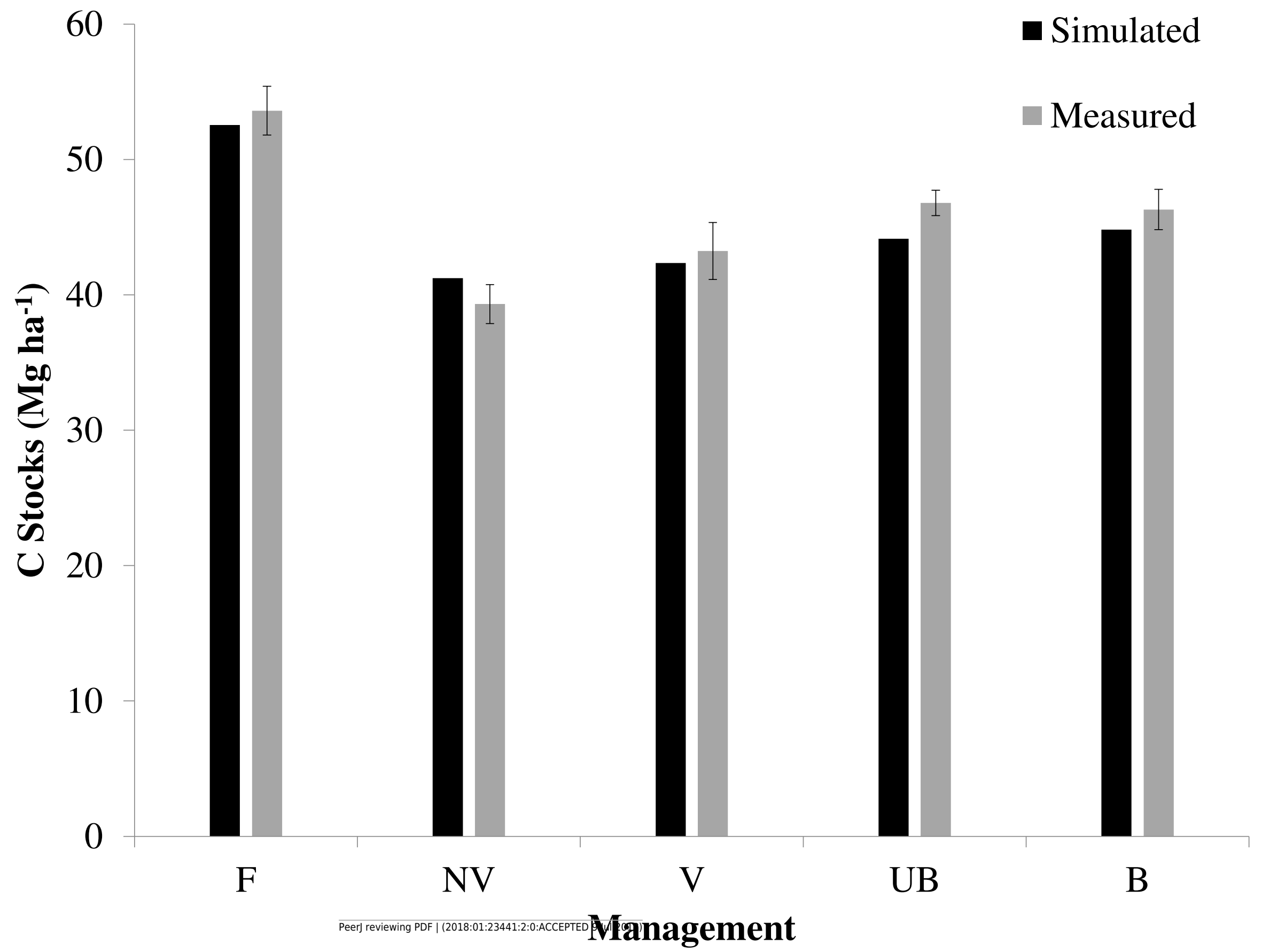


Figure 7 (on next page)

Long-term simulations of soil $C$ stocks over 87 years projection in the $0-20 \mathrm{~cm}$ soil depth including measured points (2013) for the management change situations

(a) NV to V (management change from no vinasse to vinasse-based management) and (b) $\mathrm{B}$ to UB (management change from burned to unburned management). $F$ is the native vegetation sampled by Franco et al. (2015). Vertical bars show \pm 1 standard error $(n=12)$ 


\section{Figure 8 (on next page)}

Long-term simulations of soil C stocks $(0-20 \mathrm{~cm})$ over 87 years projection for burned system and unburned system with different dosages of vinasse

(a) burned system (B), (b) unburned system (UB). High vinasse dosages (HV), low vinasse dosages (LV), standard vinasse dosages (V). $F$ is the native vegetation from Franco et al. (2015) 


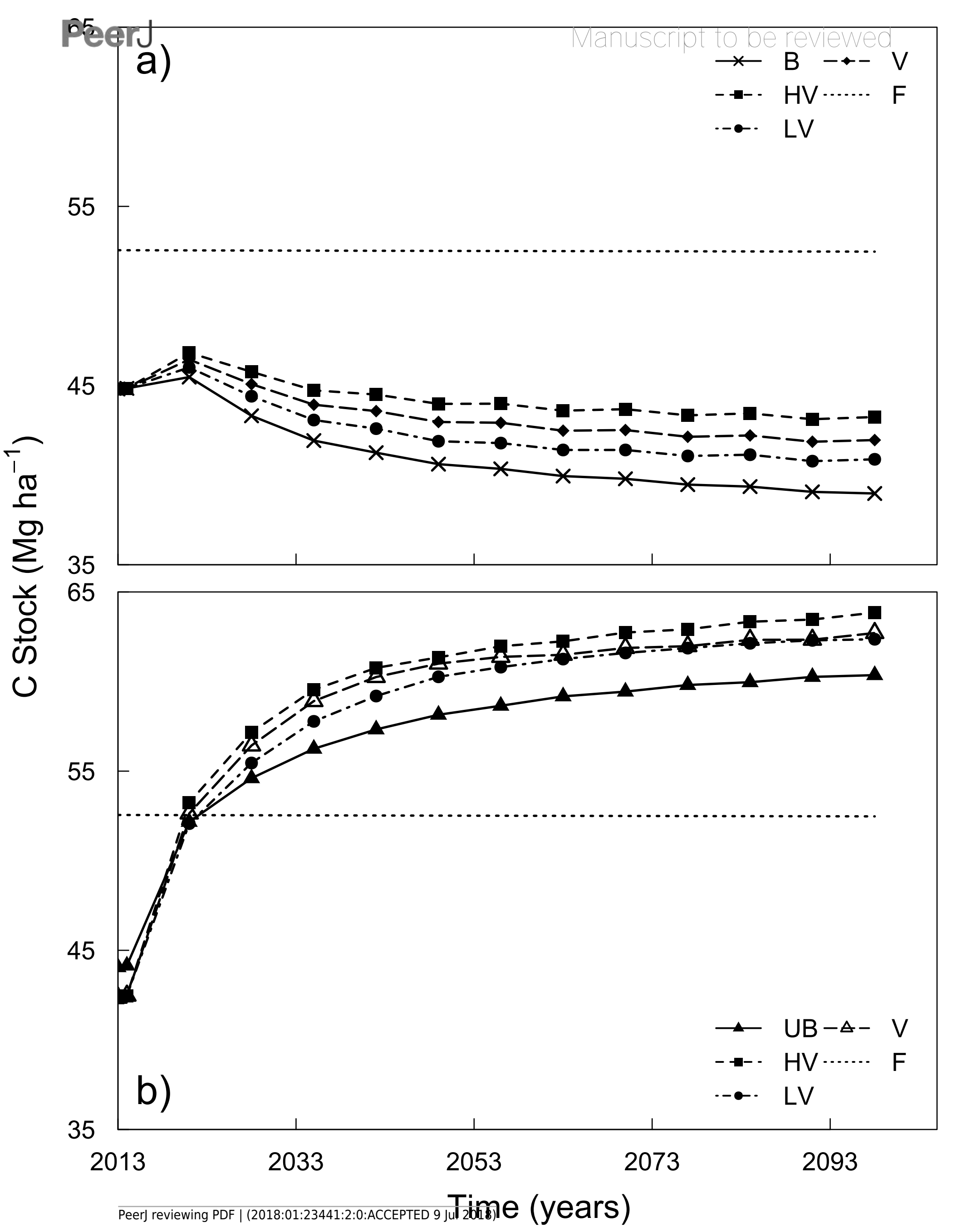




\section{Table $\mathbf{1}$ (on next page)}

Effect of management change on soil carbon stocks ( $\left.\mathrm{Mg} \mathrm{ha}^{-1}\right)$, management change factor and $C$ sequestration potential in the depth increments $0-30,0-50$ and $0-100 \mathrm{~cm}$

no vinasse (NV), vinasse (V), burned (B), unburned (UB). Standard error for 0-30 $\mathrm{cm}$ depth increment based on $n=12$, while for $0-50$ and $0-100 \mathrm{~cm}$ depth based on $n=6$. 


\begin{tabular}{|c|c|c|c|c|c|c|c|}
\hline \multirow[t]{2}{*}{$\begin{array}{l}\text { Management change } \\
\text { comparison }\end{array}$} & \multirow{2}{*}{$\begin{array}{l}\text { Time } \\
\text { span } \\
\text { (years) }\end{array}$} & \multirow[t]{2}{*}{ Depth (cm) } & \multicolumn{2}{|c|}{ Soil C stocks (Mg ha-1) } & \multirow{2}{*}{$\begin{array}{l}\text { Management } \\
\text { change } \\
\text { factors }\end{array}$} & \multirow{2}{*}{$\begin{array}{l}\text { C sequestration } \\
\left(\mathrm{Mg} \mathrm{CO}_{2} \mathrm{ha}^{-1}\right)\end{array}$} & \multirow{2}{*}{$\begin{array}{c}\mathrm{C} \text { sequestration } \\
\text { rate } \\
\left(\mathrm{Mg} \mathrm{CO}_{2} \mathrm{ha}^{-1} \mathbf{y}^{-1}\right)\end{array}$} \\
\hline & & & $\begin{array}{c}\text { Previous } \\
\text { management }\end{array}$ & $\begin{array}{c}\text { New } \\
\text { management }\end{array}$ & & & \\
\hline \multirow{3}{*}{$\mathrm{NV}$ to $\mathrm{V}$} & \multirow{3}{*}{10} & $0-30$ & $54.8 \pm 0.3$ & $60.3 \pm 0.7$ & 1.10 & 20.0 & 2.0 \\
\hline & & $0-50$ & $75.2 \pm 0.9$ & $86.3 \pm 1.7$ & 1.14 & 40.6 & 4.1 \\
\hline & & $0-100$ & $119.5 \pm 1.0$ & $130.4 \pm 1.8$ & 1.09 & 40.2 & 4.0 \\
\hline \multirow{3}{*}{$\mathrm{B}$ to $\mathrm{UB}$} & \multirow{3}{*}{12} & $0-30$ & $63.1 \pm 0.6$ & $65.2 \pm 0.4$ & 1.03 & 7.8 & 0.7 \\
\hline & & $0-50$ & $81.8 \pm 1.4$ & $91.8 \pm 0.9$ & 1.12 & 33.1 & 2.8 \\
\hline & & $0-100$ & $117.0 \pm 1.5$ & $121.7 \pm 1.1$ & 1.04 & 17.3 & 1.4 \\
\hline
\end{tabular}

2 


\section{Table 2 (on next page)}

Adjusted payback time for sugarcane ethanol considering both land use conversions assessed by Mello et al., (2014) and the effects of management change potential

Depth increments 0-30, 0-50 and 0-100 $\mathrm{cm}$ no vinasse to vinasse (NV-to-V sites, respectively), burned to unburned (B-to-UB sites, respectively). NC means not calculated by Mello et al., 2014. * Taking into account the total C debt found by Mello et al. (2014) due to LUC after 20 years and our findings regarding the management change plus sugarcane

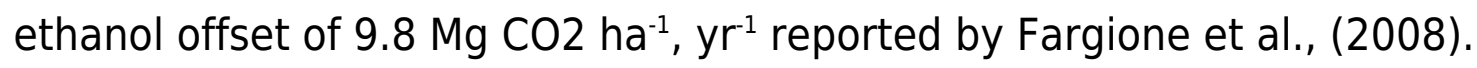


1

\begin{tabular}{|c|c|c|c|c|c|}
\hline \multirow{2}{*}{$\begin{array}{l}\text { Land use } \\
\text { conversion }\end{array}$} & \multirow{2}{*}{$\begin{array}{c}\text { Depth } \\
\text { (cm) }\end{array}$} & \multirow{2}{*}{$\begin{array}{c}\mathrm{C} \text { debt }\left(\mathrm{Mg} \mathrm{CO}_{2} \mathrm{ha}^{-1}\right) \\
\text { in } 20 \text { years } \\
\text { (Mello et al., 2014) }\end{array}$} & \multirow{2}{*}{$\begin{array}{c}\text { Average Payback time } \\
\text { (years) } \\
\text { (Mello et al., 2014) }\end{array}$} & \multicolumn{2}{|c|}{ Recalculate Payback time (years)* } \\
\hline & & & & NV-vs-V & B-vs-UB \\
\hline \multirow{3}{*}{ Pasture } & $0-30$ & 20.7 & 2.1 & 1.8 & 2.0 \\
\hline & $0-50$ & 26.8 & 2.7 & 1.9 & 2.1 \\
\hline & $0-100$ & 31.8 & 3.2 & 2.3 & 2.8 \\
\hline \multirow{3}{*}{ Cerrado } & $0-30$ & 77.2 & 7.9 & 6.5 & 7.4 \\
\hline & $0-50$ & $\mathrm{NC}$ & $\mathrm{NC}$ & $\mathrm{NC}$ & $\mathrm{NC}$ \\
\hline & $0-100$ & $\mathrm{NC}$ & $\mathrm{NC}$ & $\mathrm{NC}$ & $\mathrm{NC}$ \\
\hline
\end{tabular}

2 